\title{
Vitamin D and inflammatory diseases
}

This article was published in the following Dove Press journal:

Journal of Inflammation Research

29 May 2014

Number of times this article has been viewed

\section{Kai Yin \\ Devendra K Agrawal}

Center for Clinical and Translational Science, Creighton University School of Medicine, Omaha, NE, USA
Correspondence: Devendra K Agrawal Center for Clinical and Translational Science, Creighton University School of Medicine, 2500 California Plaza,

Omaha, NE 68178, USA

Tel + I 4022802938

Fax + I 402280 | 42 I

Email dkagr@creighton.edu
Abstract: Beyond its critical function in calcium homeostasis, vitamin D has recently been found to play an important role in the modulation of the immune/inflammation system via regulating the production of inflammatory cytokines and inhibiting the proliferation of proinflammatory cells, both of which are crucial for the pathogenesis of inflammatory diseases. Several studies have associated lower vitamin D status with increased risk and unfavorable outcome of acute infections. Vitamin D supplementation bolsters clinical responses to acute infection. Moreover, chronic inflammatory diseases, such as atherosclerosis-related cardiovascular disease, asthma, inflammatory bowel disease, chronic kidney disease, nonalcoholic fatty liver disease, and others, tend to have lower vitamin D status, which may play a pleiotropic role in the pathogenesis of the diseases. In this article, we review recent epidemiological and interventional studies of vitamin D in various inflammatory diseases. The potential mechanisms of vitamin D in regulating immune/ inflammatory responses in inflammatory diseases are also discussed.

Keywords: asthma, atherosclerosis, chronic kidney disease, inflammatory bowel disease

\section{Introduction}

Vitamin D insufficiency or deficiency has increased in the general population and become an important public health issue. ${ }^{1}$ Vitamin $\mathrm{D}$ is mainly known for its favorable effects in calcium and bone metabolism. However, increasing numbers of studies have established that vitamin D insufficiency contributes to a number of diseases, suggesting a range of physiological functions of vitamin D. ${ }^{2-4}$ Several clinical studies have confirmed that vitamin D plays a crucial role in modulating innate immune responses toward various pathogens. ${ }^{5}$ Moreover, recent studies indicate that vitamin D can regulate the adaptive immune response in various inflammatory and autoimmune diseases. ${ }^{6,7}$ These results suggest the beneficial effects of vitamin D supplementation in decreasing the risk and adverse outcomes of inflammatory diseases, although the precise effect remains to be elucidated in large clinical trials.

The two major physiologically relevant forms of vitamin $\mathrm{D}$ are vitamin $\mathrm{D}_{2}$ (ergocalciferol) and vitamin $\mathrm{D}_{3}$ (cholecalciferol). In humans, vitamin $\mathrm{D}_{3}$ seems to be more effective than vitamin $\mathrm{D}_{2}$ in maintaining the circulatory level of 25-hydroxyvitamin $\mathrm{D}_{3}\left(25[\mathrm{OH}] \mathrm{D}_{3}\right)$, a stable marker of vitamin D status. ${ }^{8,9}$ The main sources of vitamin $\mathrm{D}_{3}$ are endogenous production from 7-dehydrocholesterol in the skin by ultraviolet B energy and dietary intake from foods, including egg yolk, beef liver, and milk products. ${ }^{89}$ Vitamin $\mathrm{D}_{3}$ is metabolized to $25(\mathrm{OH}) \mathrm{D}_{3}$ in the liver by vitamin $\mathrm{D} 25$-hydroxylase and then further hydroxylated by the key enzyme 25-hydroxyl vitamin $\mathrm{D}_{3}-1 \alpha$-hydroxylase (CYP27B1) to the biologically active form: calcitriol 
(1,25-dihydroxycholecalciferol $\left.\left[1,25\{\mathrm{OH}\}_{2} \mathrm{D}_{3}\right]\right) \cdot{ }^{10}$ $1,25(\mathrm{OH})_{2} \mathrm{D}_{3}$ binds and activates the vitamin $\mathrm{D}$ receptor (VDR), a member of the superfamily of nuclear receptors and functions as a ligand-activated transcription factor. ${ }^{11}$ It is now well recognized that CYP27B1 and VDR are expressed in cells involved in the immune/inflammation system in the human body, ${ }^{12}$ which provides the biological basis for the role of vitamin $\mathrm{D}$ in inflammatory diseases.

Most clinical studies support the view that serum $25(\mathrm{OH}) \mathrm{D}_{3}$ levels of less than $20 \mathrm{ng} / \mathrm{mL}$ (50 nmol/L) indicate vitamin D deficiency. Serum $25(\mathrm{OH}) \mathrm{D}_{3}$ levels below 30 $\mathrm{ng} / \mathrm{mL}$ indicate insufficiency, while levels between 30 and $60 \mathrm{ng} / \mathrm{mL}$ (75 and $150 \mathrm{nmol} / \mathrm{L}$ ) represent normal values. ${ }^{1,13}$ Epidemiological studies suggest an inverse association between circulating levels of $25(\mathrm{OH}) \mathrm{D}_{3}$ and inflammatory markers, including CRP and interleukin (IL)-6. ${ }^{14}$ Supplemental vitamin D and calcium have been found to decrease the biomarkers of inflammation. ${ }^{15,16}$ However, a role for supplementation of vitamin D in modifying inflammatory disease has not been well defined, and it is unclear at present whether vitamin D status is causally related to the pathogenesis of the disease or is merely a marker of health. ${ }^{17}$ This review summarizes and critically evaluates the data from preclinical, epidemiological, and interventional studies in order to elucidate the role and mechanisms of vitamin D in inflammatory diseases.

\section{Vitamin D signaling and immune/inflammation system}

VDR expression has been documented in macrophages, a crucial cell type in the innate immune response. ${ }^{18}$ In macrophages, activation of the toll-like receptor (TLR1/2) heterodimer by Mycobacterium tuberculosis results in the upregulation of VDR and CYP27B1, leading to induction of the antimicrobial peptide cathelicidin and the killing of intracellular M. tuberculosis. ${ }^{19}$ In this process, IL-15 links TLR2/1-induced macrophage differentiation to the vitamin D-dependent antimicrobial pathway. ${ }^{20}$ The increase of CYP27B1 results in the accumulation of $1,25(\mathrm{OH})_{2} \mathrm{D}_{3}$, which further activates VDR, leading to the target gene transcription via vitamin $\mathrm{D}$ response elements located in the regulatory regions of $1,25(\mathrm{OH})_{2} \mathrm{D}_{3}$ target genes. ${ }^{21}$ Chen et $\mathrm{al}^{22}$ found that $1,25(\mathrm{OH})_{2} \mathrm{D}_{3}$ can regulate TLR signaling via stimulating SOCS1 by downregulating miR-155 in macrophages, which provide a novel negative feedback regulatory mechanism for vitamin $\mathrm{D}$ to control innate immunity. In a recent study, both forms of vitamin $\mathrm{D}-1,25(\mathrm{OH})_{2} \mathrm{D}_{3}$ and $25(\mathrm{OH}) \mathrm{D}_{3}-$ dose-dependently inhibited lipopolysaccharide-induced p38 phosphorylation, IL-6, and TNF $\alpha$ production by human monocytes via histone $\mathrm{H} 4$ in an acetylation-dependent manner. ${ }^{23}$ Moreover, $1,25(\mathrm{OH})_{2} \mathrm{D}_{3}$ or its analogs have been shown to initiate the differentiation of myeloid progenitors into macrophages, ${ }^{24}$ and to reduce MCP-1 and IL-6 expression via inhibiting the activation of NF- $\mathrm{KB}$ in macrophages. ${ }^{25} \mathrm{In}$ addition, Vitamin D has been thought to be a natural endoplasmic reticulum stress reliever, ${ }^{26}$ and can selectively suppress key effector functions of interferon (IFN)- $\gamma$-activated macrophages. ${ }^{27}$ Interestingly, in the presence of $1,25(\mathrm{OH})_{2} \mathrm{D}_{3}$, VDR has also been found to repress gene transcription via displacing the deoxyribonucleic acid-bound nuclear factor of activated T-cells, thus repressing inflammatory cytokine expression $^{28}$ (Figure 1).

Dendritic cells (DCs) are the most potent antigenpresenting cells. A number of studies have shown that $1,25(\mathrm{OH})_{2} \mathrm{D}_{3}$ inhibits the differentiation, maturation, and immunostimulatory capacity of human DCs, characterized as the tolerogenic properties, in a VDR-dependent manner. ${ }^{29,30}$ Molecular mechanisms underlying the modulation of tolerogenic properties of DCs by $1,25(\mathrm{OH})_{2} \mathrm{D}_{3}$ include decreasing surface expression of major histocompatibility complex II and costimulatory molecules (CD40, CD80, CD86), upregulating inhibitory immunoglobulinlike transcript 3 molecules, and enhancing secretion of chemokine (C-C motif) ligand 22 and IL-1029,31 (Figure 2). The enhancement of DC tolerogenicity by $1,25(\mathrm{OH})_{2} \mathrm{D}_{3}$ results in the induction of T-regulatory cells, a critical event for suppressing the inflammatory response of T-effector cells. ${ }^{31} 1,25(\mathrm{OH})_{2} \mathrm{D}_{3}$ also acts directly with VDR on the T lymphocyte to inhibit its proliferation. ${ }^{32}$ Although native T-cells did not express VDR, VDR expression was induced by T-cell antigen-receptor signaling via the alternative p38 MAPK pathway, which is crucial for T-cell antigen-receptor responsiveness in naïve T-cells. ${ }^{33}$ Recent work has revealed that $1,25(\mathrm{OH})_{2} \mathrm{D}_{3}$ inhibited production of proinflammatory cytokines, including IFN $\gamma$, IL-17, and IL-21 in CD4 ${ }^{+} \mathrm{CD} 25^{-}$ $\mathrm{T}$ lymphocytes, and promoted development of T-regulatory cells expressing cytotoxic T-lymphocyte antigen 4 and FOXP3 ${ }^{34}$ (Figure 2). T-cell cytokines also control vitamin D metabolism in macrophages. For example, IFN $\gamma$, a T-helper (Th)-1 cytokine, upregulates the macrophage CYP27B1, leading to enhanced bioconversion of $25(\mathrm{OH}) \mathrm{D}_{3}$ to its active metabolite $-1,25(\mathrm{OH})_{2} \mathrm{D}_{3}$. In contrast, the Th2 cytokine IL-4 induces catabolism of $25(\mathrm{OH}) \mathrm{D}_{3}$ to the inactive metabolite $24,25(\mathrm{OH})_{2} \mathrm{D}_{3},{ }^{35}$ suggesting a potential mechanism by which vitamin $\mathrm{D}$ metabolism links the cell-mediated immune responses to the innate immune responses, although the exact role of vitamin $\mathrm{D}$ in this process remains unclear. 


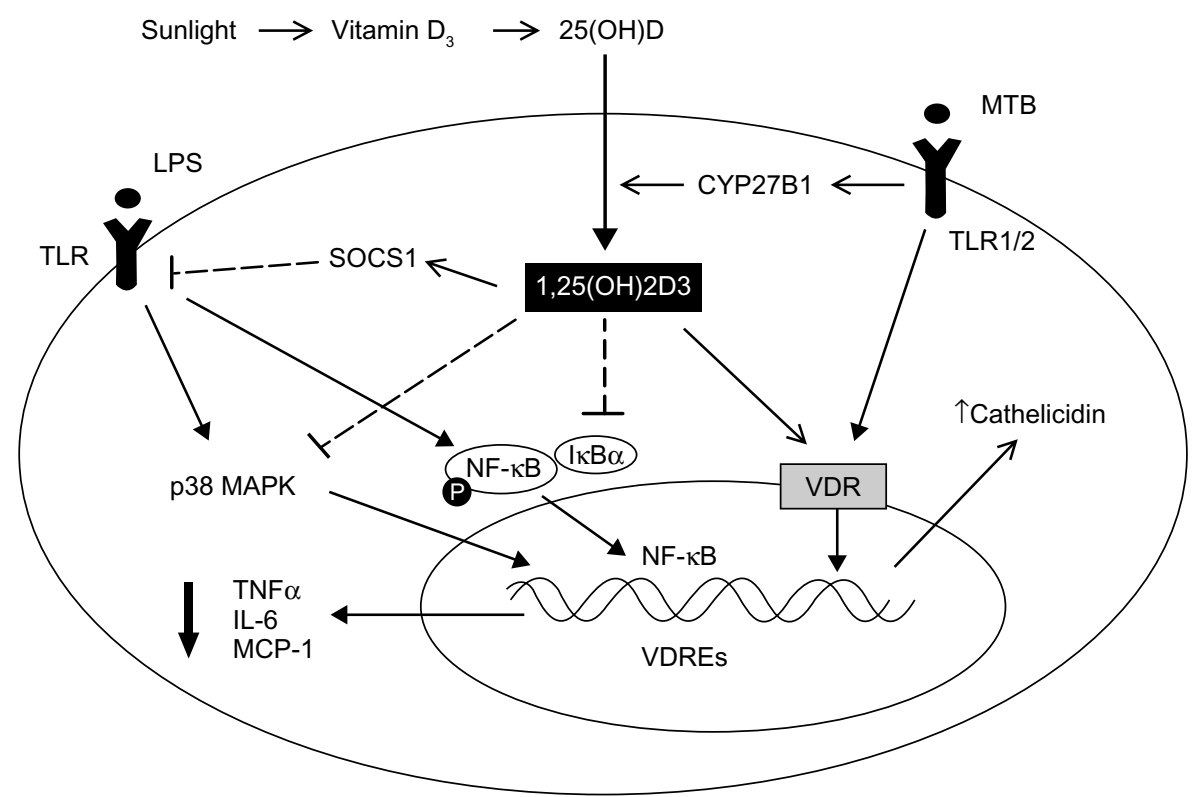

Figure I Schematic representation of the primary mechanisms through which vitamin $D$ regulates macrophage-mediated innate immune response.

Notes: Vitamin $D$ from sunlight or dietary sources is hydroxylated by the 25 -hydroxylase to form its major circulating form $-25(\mathrm{OH}) \mathrm{D}_{3}$. $25(\mathrm{OH}) \mathrm{D}_{3}$ is then hydroxylated by I $\alpha$-hydroxylase (CYP27BI) to form the hormonal form of vitamin $D-1,25(\mathrm{OH})_{2} \mathrm{D}_{3}$. I, $25(\mathrm{OH})_{2} \mathrm{D}_{3}$ acts to modulate TLR signaling via stimulating SOCSI, inhibiting the phosphorylation of $\mathrm{P} 38 \mathrm{MAPK}$ and activation of NF- $\mathrm{KB}$ signaling in human macrophages, which reduces the gene expression and protein release of proinflammatory mediators, such as TNF $\alpha$, IL-6, and MCP-I, leading to decreased recruitment of monocytes/macrophages and overall inflammation within tissue. In addition, I,25(OH) ${ }_{2} \mathrm{O}_{3}$ acts to increase the production of the antimicrobial peptide cathelicidin and the killing of intracellular mycobacterium tuberculosis (MTB).

Abbreviations: LPS, lipopolysaccharide; VDR, vitamin D receptor; VDREs, vitamin D response elements; IL-6, interleukin-6; MAPK, mitogen-activated protein kinase; MCP-I, monocyte chemoattractant protein-I; TLR, toll-like receptor; TNF $\alpha$, tumor necrosis factor- $\alpha$.

\section{Vitamin D and inflammatory diseases \\ Acute infections}

Epidemiology studies have indicated seasonal variations

in influenza and pneumococcal community-acquired pneumonia, suggesting an association between vitamin D insufficiency due to less sun exposure and acute respiratory infection (ARI) ${ }^{36}$ A number of clinical studies have suggested an inverse association between $25(\mathrm{OH}) \mathrm{D}_{3}$ levels and ARI (Table 1). ${ }^{37-42}$ Ginde et $\mathrm{al}^{41}$ performed a secondary analysis

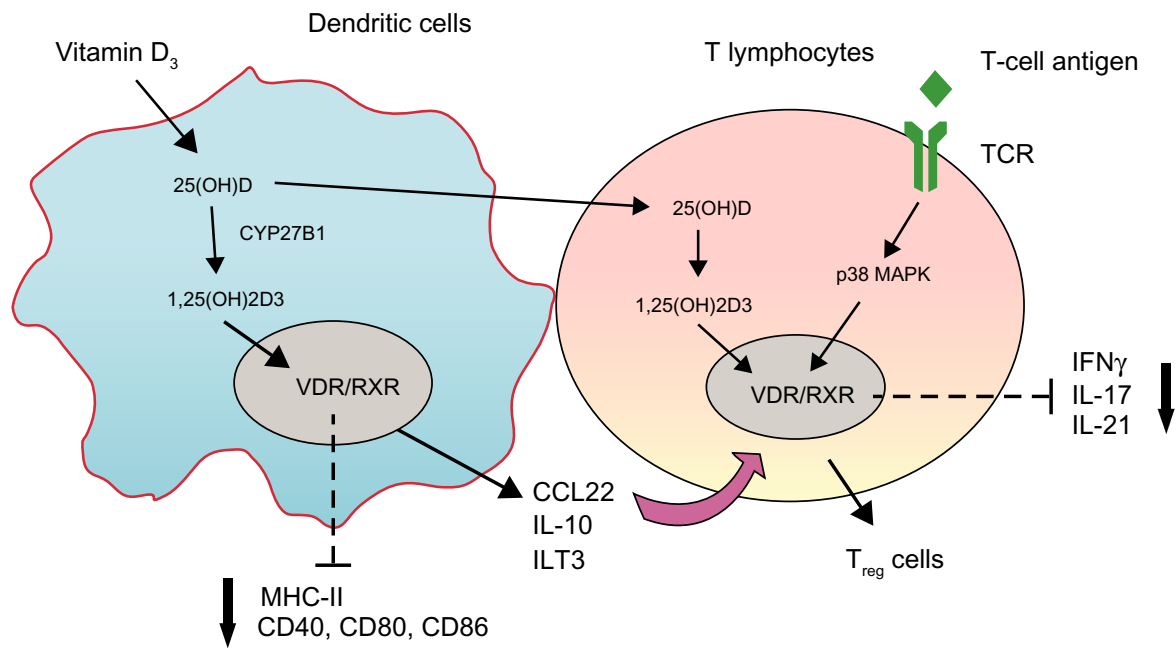

Figure 2 Schematic representation of the primary mechanisms through which vitamin D-regulated dendritic cells (DCs) and T-lymphocyte function.

Notes: Vitamin $D$ precursors can be further processed to their active metabolite, $1,25(\mathrm{OH})_{2} \mathrm{D}_{3}$, in $\mathrm{DCs}$ and $\mathrm{T}$ lymphocytes. In $\mathrm{DCs}$, I,25(OH) $\mathrm{D}_{3}$ binds to the vitamin $\mathrm{D}$ receptor-retinoid $X$ receptor (VDR/RXR) complex in the nucleus, leading to a tolerogenic DC phenotype, characterized by decreased expression of major histocompatibility complex (MHC)-II, CD40, CD80, CD86, enhanced expression of immunoglobulin-like transcript (ILT)-3, and increased secretion of interleukin (IL)-I0 and CCL22, which results in the induction of T-regulatory $\left(\mathrm{T}_{\text {reg }}\right)$ cells. The $\mathrm{I}, 25(\mathrm{OH})_{2} \mathrm{D}_{3}$ signaling in T-cells is dependent on the stimulation of T-cell antigen-receptor (TCR) signaling. VDR expression can be induced by TCR signaling via the alternative 38 MAPK pathway. $1,25(\mathrm{OH})_{2} \mathrm{D}_{3}$ binds to VDR, leading to inhibition of proinflammatory cytokine expression, including interferon (IFN)- $\gamma$, IL-I7, and IL-2I, and promotion of the development of $\mathrm{T}_{\text {reg }}$ cells.

Abbreviations: CCL22, chemokine (C-C motif) ligand 22; MAPK, mitogen-activated protein kinase. 
Table I Summary of the major clinical studies evaluating the relationship between vitamin D status and acute respiratory infections

\begin{tabular}{|c|c|c|c|c|}
\hline Source & Study design & Condition & Population (cases) & Main outcome(s) \\
\hline Ginde et $\mathrm{al}^{41}$ & $\begin{array}{l}\text { Retrospective study } \\
\text { (secondary analysis of the } \\
\text { US NHANES III data) }\end{array}$ & $25(\mathrm{OH}) \mathrm{D}_{3}$ levels $<30 \mathrm{ng} / \mathrm{mL}$ & I8,883 participants & $\begin{array}{l}\text { Serum } 25(\mathrm{OH}) \mathrm{D}_{3} \text { levels were } \\
\text { inversely associated with recent } \\
\text { upper respiratory tract infections } \\
\text { (URTIs) }\end{array}$ \\
\hline Berry et a $\left.\right|^{39}$ & $\begin{array}{l}\text { Retrospective study (secondary } \\
\text { analysis of the Nationwide } \\
\text { 1958 British Birth Cohort data) }\end{array}$ & $25(\mathrm{OH}) \mathrm{D}_{3}$ levels $>10 \mathrm{ng} / \mathrm{mL}$ & 6,789 participants & $\begin{array}{l}\text { Vitamin D status had a linear } \\
\text { relationship with respiratory } \\
\text { infections and lung function }\end{array}$ \\
\hline Sabetta et al ${ }^{40}$ & $\begin{array}{l}\text { Cross-sectional (prospective } \\
\text { from Troms } \varnothing \text { Study) }\end{array}$ & $25(\mathrm{OH}) \mathrm{D}_{3}$ levels $>38 \mathrm{ng} / \mathrm{mL}$ & $\begin{array}{l}198 \text { healthy adult } \\
\text { participants }\end{array}$ & $\begin{array}{l}25(\mathrm{OH}) \mathrm{D}_{3} \text { levels }>38 \mathrm{ng} / \mathrm{mL} \text { were } \\
\text { associated with reduction in risk of } \\
\text { viral URI }\end{array}$ \\
\hline Laaksi et $\mathrm{al}^{42}$ & $\begin{array}{l}\text { Cross-sectional (prospective } \\
\text { Tromsø Study) }\end{array}$ & $25(\mathrm{OH}) \mathrm{D}_{3}$ levels $<40 \mathrm{nmol} / \mathrm{L}$ & 800 young Finnish men & $\begin{array}{l}\text { Serum vitamin } D \text { concentrations } \\
\text { with acute respiratory tract infection } \\
(A R T I) \text { in young Finnish men }\end{array}$ \\
\hline Science et $\mathrm{a}^{37}$ & $\begin{array}{l}\text { Cross-sectional (prospective } \\
\text { cohort study) }\end{array}$ & $\begin{array}{l}\text { Median serum } 25(\mathrm{OH}) \mathrm{D}_{3} \\
\text { level } 62.0 \mathrm{nmol} / \mathrm{L}\end{array}$ & $\begin{array}{l}743 \text { participants (children } \\
\text { aged 3-15 years) }\end{array}$ & $\begin{array}{l}\text { Lower serum } 25(\mathrm{OH}) \mathrm{D}_{3} \text { levels were } \\
\text { associated with increased risk of } \\
\text { viral } \mathrm{RTI} \text { in children }\end{array}$ \\
\hline $\begin{array}{l}\text { Mohamed and } \\
\text { Al-Shehri }{ }^{38}\end{array}$ & $\begin{array}{l}\text { Cross-sectional (prospective } \\
\text { Tromsø Study) }\end{array}$ & $\begin{array}{l}\text { Cord blood } \\
\text { 25-hydroxyvitamin D levels }\end{array}$ & 206 newborns & $\begin{array}{l}\text { Low cord blood } 25(\mathrm{OH}) \mathrm{D}_{3} \text { levels } \\
\text { were associated with increased risk } \\
\text { of } A R T I \text { in the first } 2 \text { years of life }\end{array}$ \\
\hline Camargo et $\mathrm{al}^{43}$ & $\begin{array}{l}\text { Double-blinded randomized } \\
\text { clinical trials }\end{array}$ & $\begin{array}{l}\text { Vitamin } D_{3} \text { supplementation } \\
(300 \mathrm{IU})\end{array}$ & 744 school children & $\begin{array}{l}\text { Vitamin D supplementation } \\
\text { ( } 300 \mathrm{IU} / \text { daily) significantly reduced } \\
\text { the risk of ARTI in winter among } \\
\text { children with vitamin D deficiency }\end{array}$ \\
\hline Laaksi et $\mathrm{al}^{44}$ & $\begin{array}{l}\text { Double-blinded randomized } \\
\text { clinical trials }\end{array}$ & $\begin{array}{l}\text { Vitamin } D_{3} \text { supplementation } \\
(400 \mathrm{IU})\end{array}$ & I64 young Finnish men & $\begin{array}{l}400 \text { IU vitamin } D_{3} \text { daily significantly } \\
\text { decreased the risk of } A R T I \text { in young } \\
\text { Finnish men }\end{array}$ \\
\hline
\end{tabular}

Abbreviation: US NHANES, United States National Health and Nutrition Examination Survey.

of the Third National Health and Nutrition Examination Survey, and found a strong negative association between serum $25(\mathrm{OH}) \mathrm{D}_{3}$ levels $(<30 \mathrm{ng} / \mathrm{mL})$ and risk of upper respiratory tract infection, which seemed to be stronger in individuals with asthma and chronic obstructive pulmonary disease. In a large retrospective study, vitamin D status was found to have a linear association with seasonal infections and lung function, in which each $10 \mathrm{nmol} / \mathrm{L}$ increase in $25(\mathrm{OH})$ $\mathrm{D}_{3}$ was associated with a $7 \%$ lower risk of infection and an $8 \mathrm{~mL}$ increase in forced expiratory volume in 1 second. ${ }^{39}$ Several prospective cohort studies in adults and children further demonstrated that serum vitamin D concentration was associated with acute respiratory tract infection (ARTI): $25(\mathrm{OH}) \mathrm{D}_{3}$ levels $<38 \mathrm{ng} / \mathrm{mL}$ were associated with increased risk of ARTI. ${ }^{37,40,42}$ Recently, Mohamed et al ${ }^{38}$ found that low cord blood $25(\mathrm{OH}) \mathrm{D}_{3}$ levels are associated with increased risk of ARTI in the first 2 years of life, suggesting a necessary early intervention for vitamin D starting from newborns.

Evidence from double-blinded randomized clinical trials (RCTs) for vitamin D interventional studies is warranted to confirm the clinically relevant effect of vitamin D in RTIs. Camargo et al ${ }^{43}$ investigated whether vitamin $\mathrm{D}$ supplementation in children with vitamin D deficiency would lower the risk of ARI. Compared with controls, children receiving vitamin D (300 IU/daily) have been reported to have significantly fewer ARIs during the study period. In another placebo-controlled double-blinded study comprising 164 voluntary young Finnish men (18-28 years of age), the proportion of men remaining healthy throughout the 6-month study period was greater in the intervention group (vitamin $\mathrm{D}_{3}, 400 \mathrm{IU} /$ daily) than in the placebo group. ${ }^{44}$ More RCTs with larger populations, however, are warranted to investigate the role of vitamin D supplementation on respiratory health and ARI.

Studies with VDR-knockout mice have been critical in demonstrating the relationship between vitamin $\mathrm{D}$ and acute infections. ${ }^{45-49}$ Compared with $\mathrm{VDR}^{+/+}$mice, $\mathrm{VDR}^{-/-}$mice exhibited significantly higher Chlamydia trachomatis loading and reduced clearance of chlamydial infection than wildtype $\mathrm{VDR}^{+/+}$mice, suggesting a vitamin D-VDR pathway involved in respiratory mucosal defense against infections. ${ }^{46}$ VDR-knockout mice developed an unaltered Th1 response to infection due to impaired upregulation of arginase 1 expression under Leishmania infection. ${ }^{45}$ Although $1,25(\mathrm{OH})_{2} \mathrm{D}_{3}$ inhibits the proliferation and differentiation of both $\mathrm{T}$ and B lymphocytes, the central mechanism underlying microbial eradication of vitamin $\mathrm{D}$ seems to be the inhibition of activation of TLRs in the host cell, which induces the formation of potent antimicrobial peptides. ${ }^{19,50}$ The additional 
anti-infection mechanism of vitamin D may be related to the ability to modulate inflammatory factor levels in ARI patients. $25(\mathrm{OH}) \mathrm{D}_{3}$ levels below $21 \mathrm{ng} / \mathrm{mL}$ have an inverse relationship with CRP concentration in asymptomatic ambulatory patients. ${ }^{51}$ However, these associations were not found in symptomatic patients. ${ }^{52}$ In a randomized controlled trial of vitamin D supplements (1,400 IU/week) in infants, there were no differences in plasma levels of CRP or inflammatory cytokines between the treatment group and the control group. ${ }^{53}$ The exact effects and mechanisms of vitamin D in infectious diseases therefore require further study.

The functioning of VDR is affected by gene polymorphisms, in which a start codon polymorphism (rs2228570) and three polymorphisms in the $3^{\prime}$ untranslated region (UTR) of the $V D R$ gene (rs1544410, rs7975232, and rs731236) are the most commonly studied polymorphisms in the $V D R$ gene. ${ }^{54}$ There are reports that $V D R$ polymorphism is linked to increased susceptibility to infection. Alagarasu et al have found that the frequency of the $\mathrm{C} / \mathrm{C}$ genotype of rs 7975232 was significantly lower in dengue virus infection patients (DEN) compared to health controls. ${ }^{54}$ Aslan et al examined $V D R$ gene polymorphisms in urinary tract infections, and found that the ff genotype in rs2228570 was significantly increased in UTI children with urinary tract infection. ${ }^{55}$ Rathored et al have also found that the patients with ff genotypes in rs2228570 were at high risk of multidrugresistant tuberculosis with smear-positive disease. ${ }^{56}$ In a multicenter clinical trial, Levin et al recently investigated the relationship of common variation within genes encoding the vitamin D-binding protein, megalin, cubilin, CYP27B1, CYP24A1, and VDR with low 25(OH)D levels, and found some minor alleles at rs7968585 and rs7968585 within the $V D R$ gene that were related to low $25(\mathrm{OH}) \mathrm{D}_{3} \cdot{ }^{57}$ The results of these studies suggest that $V D R$ gene polymorphisms can be important for the susceptibility of inflammatory diseases, which may be due to the lower $25(\mathrm{OH}) \mathrm{D}_{3}$ status affected by $V D R$ gene polymorphisms.

\section{Atherosclerosis-related cardiovascular disease}

It is well known that inflammation plays a key role in the development of atherosclerosis. Inflammatory cells, mainly macrophages and $\mathrm{T}$ lymphocytes, produce a wide range of inflammatory cytokines in atherosclerotic lesions, which are critically important in the progression of atherosclerosis-related cardiovascular disease (CVD).$^{58}$ Numerous studies have verified vitamin D deficiency $\left(25[\mathrm{OH}] \mathrm{D}_{3}<20 \mathrm{ng} / \mathrm{mL}\right)$ as one of the new risk factors for coronary heart disease (CHD).${ }^{59,60}$ Many potential functions of vitamin D - including protection of endothelial function, inhibition of smooth-muscle cell (SMC) proliferation, improvement of lipid profile, and others - have been thought to contribute to the antiatherogenic effect of vitamin D. ${ }^{61-63}$

Clinical studies have indicated an inverse association between $25(\mathrm{OH}) \mathrm{D}_{3}$ levels and CHD risk (Table 2). Three large retrospective studies demonstrated that $25(\mathrm{OH}) \mathrm{D}_{3}$ levels below $20 \mathrm{ng} / \mathrm{mL}$ are associated with increased risk for CHD, including hypertension, diabetes mellitus, obesity, high serum low-density lipoprotein (LDL), triglyceride (TG), and low high-density lipoprotein (HDL) levels. ${ }^{17,64,65}$ Several cross-sectional prospective studies further strengthened this evidence, which demonstrated a significant increase for allcause mortality when serum $25(\mathrm{OH}) \mathrm{D}_{3}$ levels were less than $30 \mathrm{ng} / \mathrm{mL}^{66-70}$ In a population-based cohort study, Lim et $\mathrm{al}^{71}$ reported that a low $25(\mathrm{OH}) \mathrm{D}_{3}$ concentration had a higher risk of significant coronary artery stenosis. The odds ratios were 2.08 for $25(\mathrm{OH}) \mathrm{D}_{3}$ concentration of $15-29.9 \mathrm{ng} / \mathrm{mL}$ versus at least $30 \mathrm{ng} / \mathrm{mL}$ and 3.12 for $25(\mathrm{OH}) \mathrm{D}_{3}$ concentration below $15 \mathrm{ng} / \mathrm{mL}$ versus at least $30 \mathrm{ng} / \mathrm{mL}$.

Although observational studies suggest that vitamin D deficiency or insufficiency is related to a higher risk for CVD, data from recent RCTs designed to assess the impact of vitamin D supplementation on cardiovascular outcomes are conflicting (Table 3). Some RCT results have shown that a higher intake of vitamin $\mathrm{D}$ is associated with a lower risk of CVD, especially in men, due to the improvement of vascular endothelial function and decrease in inflammation. ${ }^{72-74}$ However, most evidence at present shows that vitamin supplementation has no effect on vascular disease mortality or all-cause mortality. ${ }^{73-78}$ Since large well-controlled double-blinded RCTs aiming primarily for cardiovascular end points are still absent, whether or not vitamin D supplementation can significantly improve cardiovascular outcomes is largely unknown. At this time, larger RCTs, which can be used to evaluate the application of vitamin $\mathrm{D}$ in cardiology, have yet to be implemented.

The regulation of the immune/inflammatory response is one of the most verified mechanisms of the antiatherogenic effect of vitamin D. First, vitamin D exerts protective effects against endothelial dysfunction, an inflammatory process that precedes atherosclerosis, via multiple mechanisms, including stimulating nitric oxide production and inhibiting oxidative stress. ${ }^{59,79}$ Vitamin D has been found to inhibit contractions, which were endothelium-dependent through inhibiting cyclooxygenase- 1 expression and reactive oxygen species production. ${ }^{59,79}$ In addition, calcitriol significantly repressed the expression of cyclooxygenase 2 and promoted 
Table 2 Summary of major clinical studies evaluating the relationship between vitamin D status and cardiovascular disease (CVD) risk

\begin{tabular}{|c|c|c|c|c|}
\hline Source & Study design & Condition & Population (cases) & Main outcome(s) \\
\hline Martins et a $\left.\right|^{65}$ & $\begin{array}{l}\text { Retrospective study } \\
\text { (secondary analysis of } \\
\text { the US NHANES III data) }\end{array}$ & $\begin{array}{l}\text { Mean } 25(\mathrm{OH}) \mathrm{D}_{3} \\
\text { levels }=30 \mathrm{ng} / \mathrm{mL}\end{array}$ & $\begin{array}{l}15,088 \text { participants in } \\
\text { the US }\end{array}$ & $\begin{array}{l}\text { Serum } 25(\mathrm{OH}) \mathrm{D}_{3} \text { levels were negatively } \\
\text { associated with important } \mathrm{CVD} \text { risk factors, } \\
\text { including hypertension, diabetes mellitus, } \\
\text { obesity, and high serum TG levels }\end{array}$ \\
\hline Ponda et $\mathrm{al}^{17}$ & $\begin{array}{l}\text { Cross-sectional } \\
\text { (retrospective study) }\end{array}$ & $25(\mathrm{OH}) \mathrm{D}_{3}$ levels $<20 \mathrm{ng} / \mathrm{mL}$ & $\begin{array}{l}107,81 \text { I participants in } \\
\text { the US }\end{array}$ & $\begin{array}{l}\text { Vitamin D deficiency was associated with } \\
\text { an unfavorable lipid profile, including higher } \\
\text { TC, LDL, TG, and lower HDL }\end{array}$ \\
\hline Park and Lee ${ }^{64}$ & $\begin{array}{l}\text { Cross-sectional } \\
\text { (retrospective study) }\end{array}$ & $25(\mathrm{OH}) \mathrm{D}_{3}$ levels $<25 \mathrm{nmol} / \mathrm{L}$ & 5,559 Korean participants & $\begin{array}{l}\text { Vitamin D insufficiency was associated with } \\
\text { increased prevalence of CVD, accompanied } \\
\text { by higher waist circumference, fasting } \\
\text { glucose, LDL, and TG levels and lower } \\
\text { HDL cholesterol levels }\end{array}$ \\
\hline Wang et $\mathrm{a}^{69}$ & $\begin{array}{l}\text { Cross-sectional } \\
\text { (prospective study) }\end{array}$ & $25(\mathrm{OH}) \mathrm{D}_{3}$ levels $<15 \mathrm{ng} / \mathrm{mL}$ & $\begin{array}{l}\text { I,739 Framingham } \\
\text { offspring }\end{array}$ & $\begin{array}{l}\text { Vitamin } D \text { deficiency was associated with } \\
\text { incident CVD }\end{array}$ \\
\hline Dobnig et a $\mathrm{a}^{70}$ & $\begin{array}{l}\text { Cross-sectional } \\
\text { (prospective study) }\end{array}$ & $25(\mathrm{OH}) \mathrm{D}_{3}$ levels $<13.3 \mathrm{ng} / \mathrm{mL}$ & $\begin{array}{l}3,258 \text { participants in } \\
\text { Austria }\end{array}$ & $\begin{array}{l}\text { Low } 25(\mathrm{OH}) \mathrm{D}_{3} \text { and } \mathrm{I}, 25(\mathrm{OH})_{2} \mathrm{D}_{3} \text { levels } \\
\text { were independently associated with } \\
\text { all-cause and cardiovascular mortality }\end{array}$ \\
\hline Semba et $a^{68}$ & $\begin{array}{l}\text { Cross-sectional } \\
\text { (prospective study) }\end{array}$ & $25(\mathrm{OH}) \mathrm{D}_{3}$ levels $<10.5 \mathrm{ng} / \mathrm{mL}$ & I,006 participants in Italy & $\begin{array}{l}\text { Older community-dwelling adults with low } \\
\text { serum } 25(\mathrm{OH}) \mathrm{D}_{3} \text { levels were at higher risk } \\
\text { for all-cause and } C V D \text { mortality }\end{array}$ \\
\hline Zhao et $\mathrm{a}^{66}$ & $\begin{array}{l}\text { Cohort study } \\
\text { (prospective study) }\end{array}$ & $25(\mathrm{OH}) \mathrm{D}_{3}$ levels $<29 \mathrm{ng} / \mathrm{mL}$ & $\begin{array}{l}2,609 \text { participants with } \\
\text { hypertension in the US }\end{array}$ & $\begin{array}{l}\text { Concentrations of } 25(\mathrm{OH}) \mathrm{D}_{3} \text { were inversely } \\
\text { associated with all-cause and CVD mortality } \\
\text { among adults with hypertension in the US }\end{array}$ \\
\hline Wasson et $\mathrm{al}^{67}$ & $\begin{array}{l}\text { Cross-sectional } \\
\text { (prospective study) }\end{array}$ & $\begin{array}{l}\text { The } 25(\mathrm{OH}) \mathrm{D}_{3} \text { levels } \\
<15 \mathrm{ng} / \mathrm{mL}\end{array}$ & $\begin{array}{l}\text { I,844 ischemic heart } \\
\text { disease (IHD) patients }\end{array}$ & $\begin{array}{l}\text { Vitamin } D \text { Levels of }<15 \mathrm{ng} / \mathrm{mL} \text { were } \\
\text { associated with a hazard ratio of } 2.30 \\
(P=0.035) \text { for IHD events compared to } \\
\text { levels } \geq 30 \mathrm{ng} / \mathrm{mL}\end{array}$ \\
\hline Lim et $\mathrm{al}^{71}$ & $\begin{array}{l}\text { Cross-sectional } \\
\text { (prospective study) }\end{array}$ & $25(\mathrm{OH}) \mathrm{D}_{3}$ levels $<30 \mathrm{ng} / \mathrm{mL}$ & $\begin{array}{l}921 \text { participants with } \\
\text { hypertension in the US }\end{array}$ & $\begin{array}{l}\text { Low } 25(\mathrm{OH}) \mathrm{D}_{3} \text { concentrations were } \\
\text { independently associated with higher risk } \\
\text { of coronary artery stenosis }\end{array}$ \\
\hline
\end{tabular}

Abbreviations: TC, total cholesterol; LDL, low-density lipid; TG, triglyceride; HDL, high-density lipid; US NHANES, United States National Health and Nutrition Examination Survey.

prostaglandin catabolism, both of which reduce the level of prostaglandins and suppress proinflammatory cytokine expression in endotheliocytes ${ }^{80}$ Second, $1,25(\mathrm{OH})_{2} \mathrm{D}_{3}$ may alter macrophage function and gene expression, which is crucial in the formation of foam cells and vascular inflammation response that promote the process of atherosclerosis. ${ }^{26}$ In patients with type 2 diabetes mellitus, $1,25(\mathrm{OH})_{2} \mathrm{D}_{3}$ can inhibit foam-cell formation, and suppresses macrophage cholesterol uptake via reducing peroxisome proliferated-activated receptor- $\gamma$-dependent CD36 expression. ${ }^{81}$ In addition, vitamin $\mathrm{D}$ induces an antiatherogenic monocyte/macrophage phenotype via regulating endoplasmic reticulum stress. ${ }^{26}$ Previous studies by our group have found vitamin D deficiency causes increased proinflammatory cytokine expression in epicardial adipose tissue, which is coupled with increased inflammatory cellular infiltrate, suggesting the anti-inflammation effect of vitamin D in epicardial adipose tissue is a novel mechanism for atheroprotection. ${ }^{82}$ Third, $1,25(\mathrm{OH})_{2} \mathrm{D}_{3}$ inhibits the proliferation of vascular SMCs (VSMCs) ${ }^{83}$ and exerts protective effects against VSMC morphological changes, which further inhibit the secretion of inflammatory molecules. ${ }^{84}$

In a hypercholesterolemic swine model, our group has found that vitamin D deficiency significantly increases the expression of TNF $\alpha$ in neointimal lesions after balloon angioplasty and that calcitriol has antiproliferative properties in TNF $\alpha$-stimulated human VSMCs ${ }^{85}$ Besides the direct antiatherogenic effect, vitamin D has a variety of indirect effects on the systemic pathophysiological conditions that promote atherosclerosis, such as improving insulin resistance and hypertension..$^{59}$ However, Ponda et al ${ }^{17,77}$ recently reported repletion of $25(\mathrm{OH}) \mathrm{D}_{3}$ levels in the short term does not correct or even ameliorate dyslipidemia, suggesting that the definitive role of vitamin D in CVD remains to be elucidated.

\section{Asthma}

Asthma is a disorder characterized by varying and recurring symptoms of airflow obstruction and bronchial hyperresponsiveness in the setting of inflammation ${ }^{86}$ Epidemiologic studies suggest an association between vitamin D deficiency 
Table 3 Summary of interventional studies evaluating the effect of vitamin D supplements on cardiovascular disease (CVD) risk

\begin{tabular}{|c|c|c|c|c|}
\hline Source & Study design & Condition & Population (cases) & Main outcome(s) \\
\hline Harris et $\mathrm{al}^{72}$ & $\begin{array}{l}\text { Randomized, placebo- } \\
\text { controlled trial }\end{array}$ & $\begin{array}{l}\text { Vitamin D ( } 2,000 \text { IU/day }) \text { for } \\
\text { I } 6 \text { weeks }\end{array}$ & $\begin{array}{l}57 \text { African American } \\
\text { adults }\end{array}$ & $\begin{array}{l}\text { Vitamin D supplements ( } 2,000 \mathrm{IU} / \text { day) for } \\
16 \text { weeks were effective at improving vascular } \\
\text { endothelial function in African American adults }\end{array}$ \\
\hline $\begin{array}{l}\text { Zittermann } \\
\text { et } \mathrm{al}^{73}\end{array}$ & $\begin{array}{l}\text { Randomized, placebo- } \\
\text { controlled trial }\end{array}$ & $\begin{array}{l}\text { Vitamin } D(83 \mu g / \text { day }) \text { for } \\
\text { I year }\end{array}$ & $\begin{array}{l}200 \text { overweight } \\
\text { subjects } \\
\text { (mean } 25[\mathrm{OH}] \mathrm{D}_{3} \\
\text { levels }=12 \mathrm{ng} / \mathrm{mL} \text { ) }\end{array}$ & $\begin{array}{l}\text { Vitamin D supplements enhanced the } \\
\text { beneficial effects of weight loss on CVD } \\
\text { risk, including decreasing lipid levels and } \\
\text { inflammation }\end{array}$ \\
\hline Sun et $\mathrm{al}^{74}$ & $\begin{array}{l}\text { Cross-sectional } \\
\text { (prospective study) }\end{array}$ & $\begin{array}{l}\text { Vitamin } D(\geq 600 \mathrm{IU} / \text { day }) \text { or } \\
\text { vitamin } D(<100 \mathrm{IU} / \text { day })\end{array}$ & $\begin{array}{l}2,280,324 \text { person-years } \\
\text { of follow-up }\end{array}$ & $\begin{array}{l}\text { Higher intake of vitamin D was associated } \\
\text { with a lower risk of CVD in men but not } \\
\text { in women }\end{array}$ \\
\hline Cauley et $\mathrm{al}^{75}$ & $\begin{array}{l}\text { Cross-sectional } \\
\text { (prospective study) }\end{array}$ & $\begin{array}{l}\text { Calcium plus vitamin D } \\
\text { supplementation }\end{array}$ & $\begin{array}{l}29,862 \text { postmenopausal } \\
\text { women }\end{array}$ & $\begin{array}{l}\text { There was no difference in CVD morbidity } \\
\text { between groups }\end{array}$ \\
\hline Ponda et $\mathrm{al}^{77}$ & $\begin{array}{l}\text { Randomized, placebo- } \\
\text { controlled trial }\end{array}$ & $\begin{array}{l}\text { Vitamin D }(50,000 \mathrm{IU} / \text { week }) \\
\text { for } 8 \text { weeks }\end{array}$ & $\begin{array}{l}\text { I5I vitamin D-deficient } \\
(25[\mathrm{OH}] \mathrm{D} \text { levels } \\
<20 \mathrm{ng} / \mathrm{mL}) \text { patients }\end{array}$ & $\begin{array}{l}\text { Correcting vitamin } \mathrm{D} \text { deficiency in the short } \\
\text { term did not improve the lipid profile }\end{array}$ \\
\hline Yiu et $\mathrm{a}^{78}$ & $\begin{array}{l}\text { Randomized, placebo- } \\
\text { controlled trial }\end{array}$ & $\begin{array}{l}\text { Vitamin } D(5,000 \mathrm{lU} / \text { day }) \text { for } \\
12 \text { weeks }\end{array}$ & $\begin{array}{l}100 \text { type } 2 \text { diabetes } \\
\text { mellitus patients }\end{array}$ & $\begin{array}{l}\text { I2 weeks of oral supplementation with } \\
\text { vitamin D did not significantly affect vascular } \\
\text { function or serum biomarkers of inflammation } \\
\text { and oxidative stress }\end{array}$ \\
\hline Stricker et al ${ }^{168}$ & $\begin{array}{l}\text { Randomized, placebo- } \\
\text { controlled trial }\end{array}$ & $\begin{array}{l}\text { Vitamin } D(100,000 \mathrm{IU} / \text { single } \\
\text { oral dose) }\end{array}$ & $\begin{array}{l}76 \text { patients with } \\
\text { peripheral arterial disease }\end{array}$ & $\begin{array}{l}\text { Vitamin D supplementation did not influence } \\
\text { endothelial function, arterial stiffness, } \\
\text { coagulation, or inflammation parameters }\end{array}$ \\
\hline Gepner et $\mathrm{al}^{76}$ & $\begin{array}{l}\text { Randomized, placebo- } \\
\text { controlled trial }\end{array}$ & $\begin{array}{l}\text { Vitamin } D(2,500 \mathrm{IU} / \text { day }) \text { for } \\
4 \text { months }\end{array}$ & II 4 subjects & $\begin{array}{l}\text { Vitamin D supplementation did not improve } \\
\text { endothelial function, arterial stiffness, } \\
\text { or inflammation }\end{array}$ \\
\hline
\end{tabular}

and asthma (Table 4). ${ }^{87-92}$ Some prospective studies and case-control studies have shown the majority of asthmatic children to be vitamin D-deficient. ${ }^{91,93}$ Vitamin D deficiency has been found to increase the risk of severe asthma exacerbation, defined as the need for emergency room evaluation or hospitalization. ${ }^{94}$ A prospective study of adults and children found that low serum $25(\mathrm{OH}) \mathrm{D}_{3}$ levels were associated with increased requirement of steroids in the pediatric asthma group. ${ }^{90}$ Higher maternal circulating $25(\mathrm{OH}) \mathrm{D}_{3}$ concentrations in pregnancy were independently associated with lower risk of asthma at 5 years old in offspring. ${ }^{92}$ However, another study showed that high $25(\mathrm{OH}) \mathrm{D}_{3}$ levels in pregnant women could pose an increased risk of asthma in offspring, ${ }^{95}$ indicating a reasonable level of vitamin $\mathrm{D}$ in pregnant women is crucial for maintaining normal bronchial responsiveness in offspring.

The mechanisms of vitamin D deficiency in asthma pathophysiology are not fully understood. Many researchers have focused on the potential effect of vitamin D in inflammatory response that inhibits the progress of asthma. ${ }^{86}$ Vitamin D has been found to increase the production of IL-10, an anti-inflammatory cytokine, while decreasing the expression of proinflammatory cytokines in airway SMCs. ${ }^{96,97}$ In a mouse model, Gorman et $\mathrm{al}^{98}$ recently examined asthma-like responses 24 hours after airway challenge with the experimental allergen ovalbumin in adult offspring born to vitamin $\mathrm{D}_{3}$-replete and vitamin $\mathrm{D}_{3}$-deficient mothers. They found the ability of airway-draining lymph-node cells to proliferate and secrete cytokines in response to ovalbumin ex vivo was significantly enhanced by vitamin D deficiency. ${ }^{98}$ In a mouse model of allergic airway inflammation, our group has previously found vitamin D deficiency causes an increase in the expression of TNF $\alpha$, which decreases the expression of VDR and prohibitin, a vitamin D target gene. ${ }^{95}$ Vitamin D supplementation reduces the levels of TNF $\alpha$, thereby increasing the expression of VDR and prohibitin, which could be responsible for reducing allergic airway inflammation. ${ }^{99}$

\section{Inflammatory bowel diseases}

Vitamin D deficiency is common in patients with inflammatory bowel diseases (IBDs), including ulcerative colitis (UC) and Crohn's disease (CD) ${ }^{100-105}$ (Table 5). Several retrospective and cross-sectional studies have reported a high prevalence of vitamin D deficiency in patients with IBD, which was associated with disease activity and quality of life. ${ }^{101-105}$ Recently, a prospective cohort study of 72,719 women enrolled in the Nurses' Health Study examined the relationship between vitamin D status and risk of CD and UC. ${ }^{100}$ 
Table 4 Summary of major clinical studies evaluating the relationship between vitamin D status and asthma risk

\begin{tabular}{|c|c|c|c|c|}
\hline Source & Study design & Condition & Population (cases) & Main outcome(s) \\
\hline Korn et $\mathrm{a}^{91}$ & Prospective study & $25(\mathrm{OH}) \mathrm{D}_{3}$ levels $<30 \mathrm{ng} / \mathrm{mL}$ & $\begin{array}{l}280 \text { adult asthma } \\
\text { patients }\end{array}$ & $\begin{array}{l}\text { Severe and uncontrolled adult asthma was } \\
\text { associated with vitamin } D \text { insufficiency and } \\
\text { deficiency }\end{array}$ \\
\hline Brehm et al ${ }^{169}$ & $\begin{array}{l}\text { Cross-sectional } \\
\text { study }\end{array}$ & $25(\mathrm{OH}) \mathrm{D}_{3}$ levels $<30 \mathrm{ng} / \mathrm{mL}$ & 616 children (6-14 years) & $\begin{array}{l}\text { Vitamin } D \text { insufficiency was relatively frequent in } \\
\text { an equatorial population of children with asthma; } \\
\text { lower vitamin } D \text { levels were associated with } \\
\text { increased markers of allergy and asthma severity }\end{array}$ \\
\hline Bener et $\mathrm{al}^{93}$ & $\begin{array}{l}\text { Randomized } \\
\text { compared trial }\end{array}$ & $25(\mathrm{OH}) \mathrm{D}_{3}$ levels $<30 \mathrm{ng} / \mathrm{mL}$ & $\begin{array}{l}483 \text { children with asthma } \\
\text { and } 483 \text { healthy controls }\end{array}$ & $\begin{array}{l}\text { The majority of asthmatic children had vitamin } \mathrm{D} \\
\text { deficiency compared to control children }\end{array}$ \\
\hline Freishtat et al ${ }^{89}$ & $\begin{array}{l}\text { Cross-sectional } \\
\text { case-control study }\end{array}$ & $25(\mathrm{OH}) \mathrm{D}_{3}$ levels $<30 \mathrm{ng} / \mathrm{mL}$ & $\begin{array}{l}92 \text { asthma and } \\
21 \text { controls in African } \\
\text { American youths }\end{array}$ & $\begin{array}{l}\text { The prevalence of vitamin } \mathrm{D} \text { insufficiency and } \\
\text { deficiency was significantly greater among } \\
\text { asthma cases than control subjects }\end{array}$ \\
\hline Brehm et $\mathrm{al}^{94}$ & Prospective study & $25(\mathrm{OH}) \mathrm{D}_{3}$ levels $<30 \mathrm{ng} / \mathrm{mL}$ & $\begin{array}{l}\text { I,024 children with } \\
\text { asthma }\end{array}$ & $\begin{array}{l}\text { Vitamin D insufficiency was associated with } \\
\text { higher odds of severe exacerbation over a } \\
\text { 4-year period }\end{array}$ \\
\hline Morales et a ${ }^{92}$ & $\begin{array}{l}\text { Prospective cohort } \\
\text { study }\end{array}$ & $\begin{array}{l}\text { Maternal circulating } \\
25(\mathrm{OH}) \mathrm{D}_{3} \text { levels }\end{array}$ & I,724 children & $\begin{array}{l}\text { Maternal vitamin } D \text { intake resulted in a lower } \\
\text { risk of asthma in children at } 5 \text { years of age }\end{array}$ \\
\hline Gale et $\mathrm{al}{ }^{95}$ & $\begin{array}{l}\text { Prospective cohort } \\
\text { study }\end{array}$ & $25(\mathrm{OH}) \mathrm{D}_{3}$ levels $>75 \mathrm{nmol} / \mathrm{L}$ & $\begin{array}{l}596 \text { pregnant women } \\
\text { and } 466 \text { children }\end{array}$ & $\begin{array}{l}\text { High vitamin } D \text { levels in pregnant women could } \\
\text { pose an increased risk of asthma in offspring }\end{array}$ \\
\hline Goleva et al ${ }^{90}$ & $\begin{array}{l}\text { Prospective cohort } \\
\text { study }\end{array}$ & $25(\mathrm{OH}) \mathrm{D}_{3}$ levels $<20 \mathrm{ng} / \mathrm{mL}$ & 205 adults and children & $\begin{array}{l}\text { Significant associations between serum vitamin } D \\
\text { status and steroid requirement in the pediatric } \\
\text { asthma group }\end{array}$ \\
\hline
\end{tabular}

Table 5 Summary of major clinical studies evaluating the role of vitamin D status and vitamin D supplementation in inflammatory bowel disease (IBD)

\begin{tabular}{|c|c|c|c|c|}
\hline Source & Study design & Condition & Population (cases) & Main outcome(s) \\
\hline $\begin{array}{l}\text { Ananthakrishnan } \\
\text { et al }\end{array}$ & $\begin{array}{l}\text { Prospective cohort } \\
\text { study }\end{array}$ & $25(\mathrm{OH}) \mathrm{D}_{3}$ levels $<20 \mathrm{ng} / \mathrm{mL}$ & 72,719 women & $\begin{array}{l}\text { Higher predicted plasma levels of } 25(\mathrm{OH}) \mathrm{D}_{3} \\
\text { significantly reduced the risk for incident } \\
\text { Crohn's disease }(\mathrm{CD}) \text { and insignificantly reduced } \\
\text { the risk for ulcerative colitis }(\mathrm{UC}) \text { in women }\end{array}$ \\
\hline Pappa et al ${ }^{103}$ & Cross-sectional study & $25(\mathrm{OH}) \mathrm{D}_{3}$ levels $<15 \mathrm{ng} / \mathrm{mL}$ & $\begin{array}{l}\text { I } 30 \text { IBD patients } \\
(U C=36, C D=94)\end{array}$ & $\begin{array}{l}\text { Vitamin } \mathrm{D} \text { deficiency was highly prevalent among } \\
\text { pediatric patients with IBD }\end{array}$ \\
\hline Jahnsen et al ${ }^{105}$ & Cross-sectional study & $25(\mathrm{OH}) \mathrm{D}_{3}$ levels $<30 \mathrm{nmol} / \mathrm{L}$ & $\begin{array}{l}\text { I } 20 \text { IBD patients } \\
(U C=60, C D=60)\end{array}$ & Hypovitaminosis D was common in IBD patients \\
\hline Sentongo et $\mathrm{al}^{104}$ & Cross-sectional study & $25(\mathrm{OH}) \mathrm{D}_{3}$ levels $<38 \mathrm{nmol} / \mathrm{L}$ & II 2 CD patients & Hypovitaminosis D was common in CD patients \\
\hline Ulitsky et al ${ }^{102}$ & $\begin{array}{l}\text { Retrospective cohort } \\
\text { study }\end{array}$ & $\begin{array}{l}25(\mathrm{OH}) \mathrm{D}_{3} \text { levels }<20 \mathrm{ng} / \mathrm{mL} \\
\text { or }<10 \mathrm{ng} / \mathrm{mL} \text { (deficiency or } \\
\text { severe deficiency) }\end{array}$ & $\begin{array}{l}504 \text { IBD patients } \\
(U C=10 I, C D=403)\end{array}$ & $\begin{array}{l}\text { Vitamin } D \text { deficiency was common in IBD, and was } \\
\text { independently associated with lower health-related } \\
\text { quality of life and greater disease activity in } C D\end{array}$ \\
\hline Levin et al ${ }^{101}$ & $\begin{array}{l}\text { Retrospective cohort } \\
\text { study }\end{array}$ & $\begin{array}{l}25(\mathrm{OH}) \mathrm{D}_{3} \text { levels }<50 \mathrm{nmol} / \mathrm{L} \\
\text { or }<30 \mathrm{nmol} / \mathrm{L} \text { (deficiency or } \\
\text { severe deficiency) }\end{array}$ & 78 children with IBD & $\begin{array}{l}\text { A high proportion of children with IBD were } \\
\text { vitamin D-deficient; treating vitamin } D \text { deficiency } \\
\text { is important for the management of pediatric IBD }\end{array}$ \\
\hline Jørgensen et al ${ }^{106}$ & $\begin{array}{l}\text { Randomized double- } \\
\text { blind placebo- } \\
\text { controlled trial }\end{array}$ & $\begin{array}{l}\text { Oral vitamin } D \text { with } \\
1,200 \text { IU daily for } 12 \text { months }\end{array}$ & 108 patients with $C D$ & $\begin{array}{l}\text { Oral supplementation with } I, 200 \mathrm{IU} \text { vitamin } D_{3} \\
\text { significantly reduced the risk of relapse from } \\
29 \% \text { to } 13 \%\end{array}$ \\
\hline Yang et al ${ }^{107}$ & $\begin{array}{l}\text { Randomized, } \\
\text { controlled clinical trial }\end{array}$ & $\begin{array}{l}\text { Oral vitamin D with } \\
5,000 \text { IU daily for } 24 \text { weeks }\end{array}$ & $\begin{array}{l}18 \text { mild-to-moderate } \\
\text { patients with } C D\end{array}$ & $\begin{array}{l}24 \text { weeks' supplementation with up to } \\
5,000 \mathrm{IU} / \text { day vitamin } D_{3} \text { effectively raised serum } \\
25(\mathrm{OH}) \mathrm{D}_{3} \text { and reduced } C D \text { activity index scores } \\
\text { in a small cohort of } C D \text { patients }\end{array}$ \\
\hline Pappa et al ${ }^{108}$ & $\begin{array}{l}\text { Randomized, } \\
\text { controlled clinical trial }\end{array}$ & $\begin{array}{l}\text { Vitamin } D_{2} 2,000 \mathrm{IU} / \text { day } \\
\left(\operatorname{arm~} A \text { ) or vitamin } D_{3}\right. \\
2,000 \mathrm{IU} / \text { day }(\operatorname{arm~B}) \text { or } \\
\text { vitamin } D_{2} 50,000 \mathrm{IU} / \text { week } \\
(\operatorname{arm~} C) \text { for } 6 \text { weeks }\end{array}$ & $\begin{array}{l}\text { 6I children with IBD } \\
(25[\mathrm{OH}] \mathrm{D} \text { level } \\
<20 \mathrm{ng} / \mathrm{mL})\end{array}$ & $\begin{array}{l}\text { Oral doses of } 2,000 \mathrm{IU} \text { vitamin } D_{3} \text { daily and } \\
50,000 \mathrm{IU} \text { vitamin } \mathrm{D}_{2} \text { weekly for } 6 \text { weeks was } \\
\text { superior to } 2,000 \mathrm{IU} \text { vitamin } D_{2} \text { daily for } 6 \\
\text { weeks in raising serum } 25(\mathrm{OH}) \mathrm{D} \text { concentration, } \\
\text { and was well tolerated among children and } \\
\text { adolescents with IBD }\end{array}$ \\
\hline Miheller et al ${ }^{109}$ & $\begin{array}{l}\text { Randomized, } \\
\text { controlled clinical trial }\end{array}$ & $\begin{array}{l}\mathrm{I}, 25(\mathrm{OH})_{2} \mathrm{D}_{3} \text { (active vitamin } \mathrm{D} \\
\text { or plain vitamin } \mathrm{D}[\mathrm{pVD}] \text { ) }\end{array}$ & $\begin{array}{l}37 \text { inactive } C D \\
\text { patients }\end{array}$ & $\begin{array}{l}\text { I,25(OH })_{2} D_{3} \text { had a more prominent short-term } \\
\text { beneficial effect than PVD on disease activity of CD }\end{array}$ \\
\hline
\end{tabular}


In this study, researchers used Cox proportional hazard modeling to examine the hazard ratio (HR) for incident CD or $\mathrm{UC}$ after adjusting for potential confounders. Compared with women with a predicted $25(\mathrm{OH}) \mathrm{D}_{3}$ level less than $20 \mathrm{ng} / \mathrm{mL}$, the multivariate-adjusted HR was 0.38 (95\% confidence interval 0.15-0.97) for CD and 0.57 (95\% confidence interval $0.19-1.70)$ for UC for women with a predicted $25(\mathrm{OH})$ $\mathrm{D}_{3}$ level greater than $30 \mathrm{ng} / \mathrm{mL}$, suggesting higher predicted plasma levels of $25(\mathrm{OH}) \mathrm{D}_{3}$ significantly reduce the risk for incident CD. ${ }^{100}$

Vitamin D supplementation has shown potential therapeutic benefit for IBD in some small, randomized, double-blind studies (Table 5). Jørgensen et al ${ }^{106}$ reported that oral supplementation with vitamin $\mathrm{D}_{3}(1,200 \mathrm{IU} /$ day for 12 months) significantly reduced the risk of IBD relapse from $29 \%$ to $13 \%$. Yang et $\mathrm{al}^{107}$ investigated the effect of high-dose vitamin $\mathrm{D}_{3}$ on serum vitamin $\mathrm{D}$ levels and $\mathrm{CD}$ activity index. They found supplementation of vitamin $\mathrm{D}_{3}(5,000 \mathrm{IU} /$ day for 24 weeks) effectively raised serum $25(\mathrm{OH}) \mathrm{D}_{3}$ and reduced $\mathrm{CD}$ activity index scores. Pappa et al ${ }^{108}$ reported oral doses of 2,000 IU vitamin $\mathrm{D}_{3}$ daily or $50,000 \mathrm{IU}$ vitamin $\mathrm{D}_{2}$ weekly seem to be superior to $2,000 \mathrm{IU}$ vitamin $\mathrm{D}_{2}$ daily in raising serum $25(\mathrm{OH}) \mathrm{D}_{3}$ concentration, and was tolerated among children and adolescents with IBD. Another study has shown that $1,25(\mathrm{OH})_{2} \mathrm{D}_{3}$ (active form of vitamin $\mathrm{D}$ ) has a more prominent short-term beneficial effect than $25(\mathrm{OH}) \mathrm{D}_{3}$ (plain vitamin-D) on CD activity. ${ }^{109}$ Although most studies have now shown vitamin $\mathrm{D}_{3}$ treatment might be effective in IBD, larger, randomized, double-blind, placebo-controlled trials needed to elucidate this correlation are lacking.

In VDR-knockout mice models, vitamin D deficiency increases susceptibility to dextran sodium sulfate-induced colitis. ${ }^{110}$ Histological examination revealed the disruption in the epithelial junctions in dextran sodium sulfate-treated $\mathrm{VDR}^{-/}$mice. $1,25(\mathrm{OH})_{2} \mathrm{D}_{3}$ preserved the integrity of the tight junctions in Caco-2 cell monolayers. ${ }^{110}$ Ryz et al ${ }^{111}$ found that $1,25(\mathrm{OH})_{2} \mathrm{D}_{3}$ treatment increases host susceptibility to Citrobacter rodentium, an extracellular microbe that causes acute colitis, by suppressing mucosal Th17 immune responses. Taken together, these observations suggest that vitamin D plays a critical role in mucosal barrier homeostasis by preserving the integrity of junctions via regulating the host immune/inflammatory response, leading to decreased susceptibility to mucosal damage and decreased risk of IBD.

\section{Chronic kidney disease}

Normal renal function is crucial for vitamin D metabolism. ${ }^{1}$ Vitamin D deficiency is highly prevalent among patients with chronic kidney disease (CKD; 20\%-85\%). ${ }^{112,113}$ Studies have demonstrated a strong association between vitamin $\mathrm{D}$ deficiency and increased all-cause and CKD mortality in the general population (Table 6). ${ }^{113-118}$ Chronic low-grade inflammation is a hallmark of CKD, and has been disclosed as one important factor contributing to the progression of CKD and high cardiovascular mortality. ${ }^{10}$ A prospective cohort study of 444 patients with eGFR $<60 \mathrm{~mL} / \mathrm{min} / 1.73 \mathrm{~m}^{2}$ (follow-up time 9.4 years) showed that most patients died from cardiovascular causes. ${ }^{116}$ Cox proportional hazard modeling has shown multivariate-adjusted HRs (with 95\% confidence intervals) in severely vitamin D-deficient $\left(25[\mathrm{OH}] \mathrm{D}_{3}<10 \mathrm{ng} / \mathrm{mL}\right)$ compared to vitamin D-sufficient patients $\left(25[\mathrm{OH}] \mathrm{D}_{3}\right.$ $\geq 30 \mathrm{ng} / \mathrm{mL})$ were 3.79 (1.71-8.43) for all-cause and 5.61 (1.89-16.6) for cardiovascular mortality, suggesting low $25(\mathrm{OH}) \mathrm{D}_{3}$ levels are a crucial factor linking CKD to CVD. ${ }^{116}$ Another cross-sectional study strengthened this evidence, demonstrating that higher vascular stiffness and endothelial dysfunction were associated with low levels of $25(\mathrm{OH})$ $\mathrm{D}_{3}$ and $1,25(\mathrm{OH})_{2} \mathrm{D}_{3}$ in CKD patients. ${ }^{119}$ Vitamin $\mathrm{D}$ intake for more than 12 months can significantly reduce the probability of cardiovascular events. ${ }^{117}$ Low $25(\mathrm{OH}) \mathrm{D}_{3}$ and $1,25(\mathrm{OH})_{2} \mathrm{D}_{3}$ levels are independently associated with albuminuria, a major risk factor for the progression of renal disease linked to all-cause mortality and cardiovascular mortality. ${ }^{114}$ Treatment with active vitamin D preparations also has a beneficial effect in decreasing albuminuria. ${ }^{120}$ Besides regulating inflammation and proteinuria, vitamin $\mathrm{D}$ has been found to improve aerobic capacity and increase the level of fetuin-A, an important protective factor for cardiovascular morbidity in pediatric CKD patients. ${ }^{115,121}$

Several randomized, double-blind, placebo-controlled studies have examined the role of vitamin $\mathrm{D}$ as a therapeutic agent for CKD (Table 7). ${ }^{120,122-127}$ High-dose cholecalciferol supplementation $(50,000 \mathrm{IU} /$ week for 12 weeks) was safe and sufficient to maintain serum $25(\mathrm{OH}) \mathrm{D}_{3}$ concentrations ( $\geq 30 \mathrm{ng} / \mathrm{mL}$ ) and simultaneously decreased serum MCP-1 concentrations in early CKD. ${ }^{122-124}$ In moderate CKD patients, both cholecalciferol (vitamin $\mathrm{D}_{3}$ ) and ergocalciferol (vitamin $\mathrm{D}_{2}$ ) are effective in increasing $25(\mathrm{OH}) \mathrm{D}_{3}$ and decreasing parathyroid hormone and inflammatory cytokine levels. ${ }^{125,127}$ In nonhemodialysis patients, supplementation of cholecalciferol with 40,000 IU/week for 8 weeks significantly increased the level of $1,25(\mathrm{OH})_{2} \mathrm{D}_{3}$ and decreased serum parathyroid hormone and inflammatory cytokine levels. ${ }^{126}$ However, this effect was not observed in end-stage renal disease (ESRD) patients. ${ }^{126}$ As patients with CKD progress to ESRD, renal CYP27B1 activity decreases, resulting in 
Table 6 Summary of major clinical studies evaluating the relationship between vitamin D status and chronic kidney disease (CKD) risk

\begin{tabular}{|c|c|c|c|c|}
\hline Source & Study design & Objective & Population (cases) & Main outcome(s) \\
\hline Pilz et al ${ }^{116}$ & $\begin{array}{l}\text { Prospective } \\
\text { cohort study }\end{array}$ & $\begin{array}{l}\text { To investigate the relationship } \\
\text { between the vitamin } D \text { status and } \\
\text { mortality of CKD }\end{array}$ & 444 CKD patients & $\begin{array}{l}\text { Low } 25(\mathrm{OH}) \mathrm{D}_{3} \text { levels were associated } \\
\text { with increased all-cause and cardiovascular } \\
\text { mortality in CKD patients }\end{array}$ \\
\hline Santoro et al $\left.\right|^{117}$ & $\begin{array}{l}\text { Cross-sectional } \\
\text { study }\end{array}$ & $\begin{array}{l}\text { To investigate the relationship } \\
\text { between the vitamin } D \text { status } \\
\text { and mortality of CKD }\end{array}$ & I04 CKD patients & $\begin{array}{l}\text { Vitamin D has been shown to reduce } \\
\text { the probability of cardiovascular or renal } \\
\text { events; vitamin D intake for more than } \\
\text { I } 2 \text { months can reduce the probability of } \\
\text { such events by } \mid \mathrm{I} .42 \%\end{array}$ \\
\hline London et al ${ }^{119}$ & $\begin{array}{l}\text { Cross-sectional } \\
\text { study }\end{array}$ & $\begin{array}{l}\text { To investigate the relationship } \\
\text { between vitamin } D \text { status and } \\
\text { cardiovascular risk factors }\end{array}$ & $\begin{array}{l}\text { I04 CKD patients } \\
\text { (end stage) }\end{array}$ & $\begin{array}{l}\text { Vitamin } D \text { deficiency and low } 1,25(\mathrm{OH})_{2} \mathrm{D}_{3} \\
\text { could be associated with arteriosclerosis } \\
\text { and endothelial dysfunction in } \\
\text { hemodialysis patients }\end{array}$ \\
\hline Isakova et al'14 & $\begin{array}{l}\text { Cross-sectional } \\
\text { study }\end{array}$ & $\begin{array}{l}\text { To investigate the relationship } \\
\text { between vitamin } D \text { level, } \\
\text { inflammation, and albuminuria }\end{array}$ & I,847 participants & $\begin{array}{l}\text { Low } 25(\mathrm{OH}) \mathrm{D}_{3} \text { and } \mathrm{I}, 25(\mathrm{OH})_{2} \mathrm{D}_{3} \\
\text { levels were independently associated } \\
\text { with albuminuria; vitamin } \mathrm{D} \text { deficiency } \\
\text { may contribute to inflammation and } \\
\text { subsequent albuminuria }\end{array}$ \\
\hline Petchey et $\mathrm{al}^{115}$ & $\begin{array}{l}\text { Cross-sectional } \\
\text { study }\end{array}$ & $\begin{array}{l}\text { To investigate the relationship between } \\
\text { vitamin } D \text { status and maximum aerobic- } \\
\text { exercise capacity in patients with CKD }\end{array}$ & 85 CKD participants & $\begin{array}{l}\text { Vitamin D was independently associated } \\
\text { with aerobic capacity in CKD patients }\end{array}$ \\
\hline Satirapoj et al $\left.\right|^{113}$ & $\begin{array}{l}\text { Cross-sectional } \\
\text { study }\end{array}$ & $\begin{array}{l}\text { To investigate the relationship } \\
\text { between vitamin } D \text { status and the } \\
\text { staging of CKD }\end{array}$ & 2,895 CKD patients & $\begin{array}{l}25(\mathrm{OH}) \mathrm{D}_{3} \text { insufficiency and deficiency were } \\
\text { more common and associated with level of } \\
\text { kidney function in the Thai CKD population, } \\
\text { especially in advanced-stage CKD }\end{array}$ \\
\hline Schaible et al ${ }^{121}$ & $\begin{array}{l}\text { Cross-sectional } \\
\text { study }\end{array}$ & $\begin{array}{l}\text { To investigate the effect of vitamin } D \\
\text { status on fetuin-A in CKD patients }\end{array}$ & II 2 pediatric patients & $\begin{array}{l}\text { Cumulative intake of } 25(\mathrm{OH}) \mathrm{D}_{3} \text { and } \\
\text { calcitriol were significantly correlated } \\
\text { with fetuin-A in CKD patients }\end{array}$ \\
\hline $\begin{array}{l}\text { Seeherunvong } \\
\text { et al }{ }^{118}\end{array}$ & $\begin{array}{l}\text { Cross-sectional, } \\
\text { retrospective } \\
\text { study }\end{array}$ & $\begin{array}{l}\text { To assess the prevalence of abnormal } \\
\text { vitamin } D \text { status in children and } \\
\text { adolescents with CKD }\end{array}$ & $\begin{array}{l}258 \text { patients with } \\
\text { early CKD }\end{array}$ & $\begin{array}{l}\text { Vitamin } D \text { insufficiency and deficiency may } \\
\text { contribute to growth deficits during the } \\
\text { earliest stages of CKD }\end{array}$ \\
\hline
\end{tabular}

the impaired formation of $1,25(\mathrm{OH})_{2} \mathrm{D}_{3}$ in many of these patients. ${ }^{128}$ Previous attempts to counteract these changes in mineral metabolism with nutritional vitamin D therapy have been unsuccessful. ${ }^{129}$ For this reason, most therapeutic approaches to treat vitamin D deficiency in ESRD patients favor the use of calcitriol or its associated analogs instead of the use of nutritional vitamin D forms. ${ }^{128,130}$ Interestingly, in an uncontrolled trial of seven ESRD patients, Stubbs et al ${ }^{128}$ reported significant and favorable effects after 8 weeks of cholecalciferol supplementation on circulating monocytes and concentration of inflammatory cytokines, which may be have been due to extrarenal production of calcitriol in the setting of minimal renal CYP27B1 activity in ESRD patients.

Experimental studies have demonstrated that vitamin D can control inflammation and oxidative stress that prevent CKD progress. ${ }^{131,132}$ Using a mouse model of obstructed nephropathy, Tan et $\mathrm{l}^{132}$ reported that the synthetic vitamin D analog paricalcitol reduced the infiltration of inflammatory T-cells and macrophages in the obstructed kidney, which was accompanied by a decreased expression of RANTES and TNF $\alpha$. In a human proximal tubular cell line (HKC-8), paricalcitol inhibited RANTES messenger ribonucleic acid and protein expression and abolished the ability of tubular cells to recruit lymphocytes and monocytes after TNF $\alpha$ stimulation. ${ }^{132}$ In a study using a uremic rat model, paricalcitol significantly decreased cardiac oxidative stress. When combining with the angiotensin-converting enzyme inhibitor enalapril, paricalcitol further prevented inflammation and oxidative injury in uremic rats. ${ }^{131}$ These studies provide experimental evidence supporting the role of inflammation in providing a pathological link between vitamin $\mathrm{D}$ and CKD.

\section{Liver inflammatory disease}

Nonalcoholic fatty liver disease (NAFLD) refers to the presence of hepatic steatosis without significant alcohol use or other known liver disease, and is characterized by chronic portal inflammation. ${ }^{133}$ Recent studies emphasize the role of insulin resistance, metabolic syndrome, and proinflammatory cytokines in the development and progression of NAFLD. ${ }^{134,135}$ Vitamin D serum levels negatively correlate with insulin resistance and metabolic syndrome. Supplementation of vitamin D has been found to reduce 


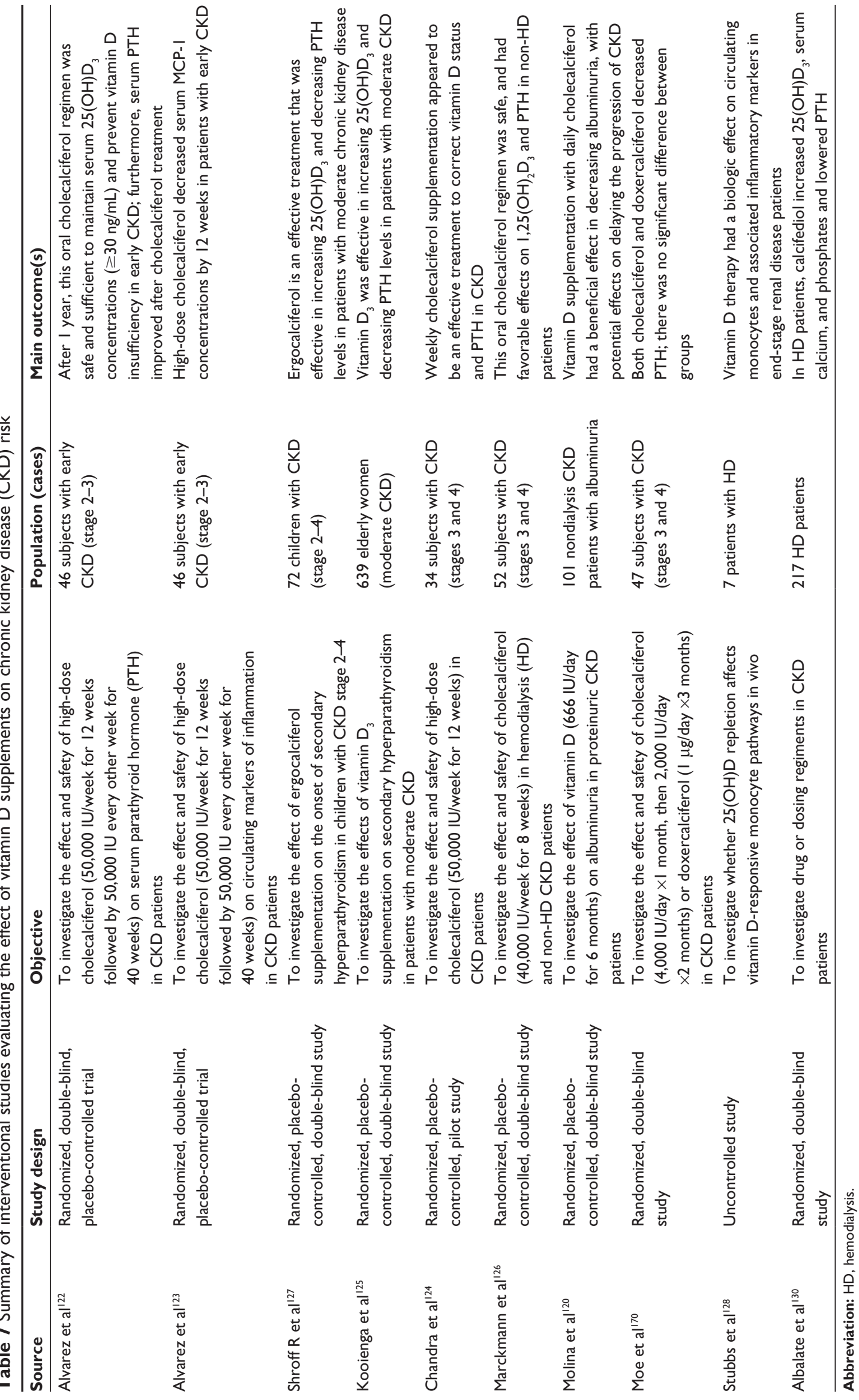


insulin resistance in obese children. ${ }^{134}$ Recently, lower vitamin D levels were found to be independently associated with increased severity of steatosis, necroinflammation, and fibrosis in NAFLD. ${ }^{136,137}$ Furthermore, serum vitamin D levels that could predict the severity of NAFLD independently of other metabolic characteristics and relate vitamin D to NAFLD are largely unknown. Considering that inflammation is followed by steatosis in most NAFLD patients, ${ }^{138}$ vitamin D may be involved in NAFLD through its ability to modulate the immune/inflammation system. Recently, Roth et al $^{139}$ fed young (25-day-old) Sprague Dawley rats with a low-fat diet alone, with vitamin $\mathrm{D}$ depletion, or with a Westernized diet, and found that vitamin D-depleted animals fed a Westernized diet exhibited significantly greater hepatic steatosis and inflammation compared to low-fat diet groups, which may be related to the upregulation of TLR2, TLR4, TLR9, and endotoxin receptor CD14 in the liver, suggesting vitamin D depletion exacerbates NAFLD, possibly by way of endotoxin exposure in a Westernized diet rat model. Low vitamin D serum levels have also been found to correlate with the severity of inflammation and fibrosis in chronic hepatitis $\mathrm{B}$ and $\mathrm{C}$ viruses, where cellular immunity played crucial roles in the progress of diseases. ${ }^{140,141}$ In hepatitis B, $V D R$ polymorphisms have been associated with infection susceptibility and clinical course in different populations. ${ }^{142}$ Taken together, these data indicate a potential link between vitamin $\mathrm{D}$ and viral hepatitis.

\section{Multiple sclerosis}

Multiple sclerosis (MS) is a chronic inflammatory disease of the central nervous system, which affects more than 2 million individuals worldwide. Growing evidence suggest that vitamin $\mathrm{D}$ deficiency might be one of the most important environmental factors for the prevalence, relapse rate, and progression of $\mathrm{MS}^{143-146}$ (Table 8). In a large prospective case-control study of 7 million US military personnel, high circulating levels of $25(\mathrm{OH}) \mathrm{D}_{3}$ were found to be associated with a lower risk of MS, in which every $50 \mathrm{nmol} / \mathrm{L}$ increase in serum $25(\mathrm{OH}) \mathrm{D}_{3}$ led to a $41 \%$ decrease in MS risk. ${ }^{145}$ Another prospective study of 35,794 mothers of participants in the Nurses' Health Study II has shown that the relative risk of MS was lower among women born to mothers with high milk or vitamin D intake during pregnancy. ${ }^{147}$ In addition, serum $25(\mathrm{OH}) \mathrm{D}_{3}$ concentrations in patients with MS were also found to be related to the relapse of the disease. Mowry et al found that each $10 \mathrm{ng} / \mathrm{mL}$ increase in $25(\mathrm{OH}) \mathrm{D}_{3}$ level was associated with a $15 \%$ lower risk of a new $T_{2}$ lesion and a $32 \%$ lower risk of a gadolinium-enhancing lesion.
Each $10 \mathrm{ng} / \mathrm{mL}$ increase in vitamin D level was associated with lower subsequent disability, suggesting higher vitamin $\mathrm{D}$ levels were associated with lower relapse risk. ${ }^{143}$

Although a link between vitamin D supplementation and decreased risk of MS has been widely assumed, present vitamin D-repletion therapies have not yet shown a significant effect on the progress of MS (Table 8). In a retrospective cohort study of 116,671 female registered nurses, intake of vitamin D ( $\geq 400$ IU/day) from multivitamins was not been found to statistically reduce the risk of MS. ${ }^{145}$ Moreover, no published RCTs of vitamin D repletion so far - low dose or high dose - have shown any benefit on relative risk of MS relapse. ${ }^{148-150}$ However, in a high-dose vitamin $\mathrm{D}_{3}$-supplementation RCT (20,000 IU/day for 12 weeks) in MS patients, vitamin D was found to increase proportion of $\mathrm{IL}-10^{+} \mathrm{CD} 4^{+} \mathrm{T}$-cells and decrease the ratio between IFN $\gamma^{+}$and IL-4 ${ }^{+} \mathrm{CD} 4^{+}$T-cells. ${ }^{151}$ Moreover, in a myelin oligodendrocyte glycoprotein-induced animal model of MS, vitamin D significantly attenuated central nervous system inflammation and demyelination, accompanied by a lower amount of IFN $\gamma$-producing myelin oligodendrocyte glycoprotein-specific T-cells via a developmental stagedependent manner. ${ }^{152}$

These results suggest the exact effect of vitamin D repletion on the risk of MS remains to be clarified, since large, high-quality, randomized trials are still lacking.

\section{Other inflammation/ immune-related disorders}

Inflammation has also been found to play an important role in other chronic diseases, including hypertension, diabetes, chronic lower-back pain (CLBP), and congestive heart failure (HF). Several reviews have thoroughly discussed the relationship between vitamin D and hypertension or diabetes. ${ }^{153,154}$ There is clear evidence to support an association between low plasma levels of $25(\mathrm{OH}) \mathrm{D}_{3}$ and hypertension and type 2 diabetes. ${ }^{153,154}$ Furthermore, clinical trials aimed at testing the effect of vitamin D supplementation on hypertension and type 2 diabetes documented a dose-dependent blood pressure-lowering and insulin sensitivity-increasing effect of vitamin D in patients. ${ }^{155-157}$ However, in a recent randomized, double-blind, placebo-controlled clinical trial, high-dose oral vitamin $\mathrm{D}_{3}(100,000 \mathrm{IU})$ for 6 months seemed not to reduce blood pressure or left ventricular mass in patients with resistant hypertension. ${ }^{158}$ Because the 6-month period used in this study may have been too short a period to detect meaningful effects of vitamin D on left ventricular mass and function, longer trials and detailed studies are needed to better 


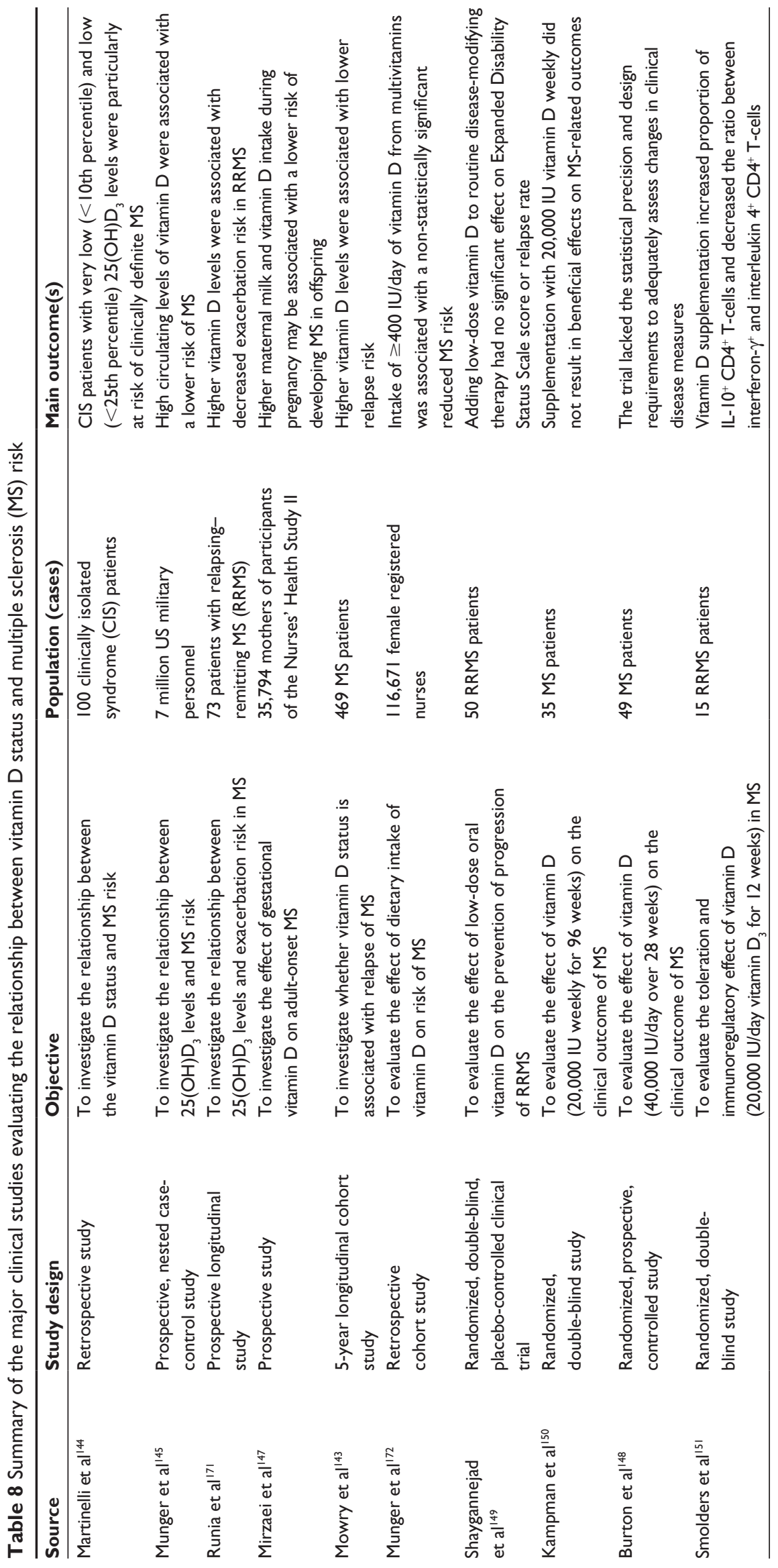


investigate the definite role of vitamin D supplementation in various forms of hypertension.

Nonspecific lower-back pain is one of the most common reasons for CLBP that burdens health care systems with high cost. Human population studies have shown that plasma levels of vitamin D are inversely associated with risk for CLBP. ${ }^{159}$ However, results from a double-blind RCT of 53 patients aged 18-40 years with nonspecific CLBP showed no significant effect of vitamin D supplementation (50,000 IU) in decreasing the pain visual analog scale score of the patients. ${ }^{160}$ Vitamin $\mathrm{D}$ deficiency is associated with loss of muscle strength and poor outcomes in patients with HF. In a double-blind RCT in 31 patients $\left(25[\mathrm{OH}] \mathrm{D}_{3}\right.$ levels $\left.\leq 37.5 \mathrm{ng} / \mathrm{mL}\right)$, vitamin $\mathrm{D}_{3}$ repletion $(50,000 \mathrm{IU})$ decreased aldosterone in patients with $\mathrm{HF}$ and low serum vitamin D, suggesting that vitamin D may be an important adjunct to standard HF therapy. ${ }^{161}$

Apart from inflammatory disorders, vitamin D deficiency has been found to be associated with immune-related disorders, such as rheumatoid arthritis and systemic lupus erythematosus. ${ }^{162,163}$ Randomized placebo-controlled trials have shown that vitamin D supplementation seems to ameliorate inflammatory and hemostatic markers and show a tendency toward subsequent clinical improvement in these diseases. ${ }^{146,163,164}$ In a healthy population, vitamin D levels were significantly higher in antinuclear antibody-negative individuals than antinuclear antibody-positive individuals. ${ }^{165}$ Along with this finding is the additional observation that vitamin $\mathrm{D}$ deficiency is associated with certain immune abnormalities in such autoimmune disorders as systemic lupus erythematosus and rheumatoid arthritis. ${ }^{163,166}$ Recently, a retrospective crosssectional study showed the risk of auto- and cellular immune abnormalities is increased in women with recurrent pregnancy losses and vitamin D deficiency. ${ }^{167}$

\section{Conclusion}

The remarkable expression of the CYP27B1 and VDR genes by macrophages, DCs, and T lymphocytes suggests that the immune/inflammation system could be a target for the effect of vitamin D. Emerging evidence from clinical studies has indicated that vitamin D deficiency is associated with several inflammatory diseases; however, the question remains whether or not vitamin D deficiency contributes to the etiology of inflammatory disease or if vitamin D deficiency is simply a manifestation of these diseases. In acute infection and autoimmune disorders, preliminary evidence suggests an important role of vitamin D supplementation in decreasing the risk of disease. The pathophysiological process in many chronic inflammatory diseases, including atherosclerosis, is complex and confounded by various metabolic factors. Whether vitamin D supplementation is beneficial in the prognosis of these diseases requires further evaluation in larger prospective trials with a focus on major outcome events. In addition, dose-response randomized trials are necessary to identify threshold effects and possible adverse effects in vitamin D therapy. Future studies should aim to characterize optimal ranges of vitamin D status following vitamin $\mathrm{D}$ therapy, and should focus on determining the exact relationship between vitamin D dose and outcomes during the progression of diseases.

The identification and characterization of the molecular mechanisms responsible for recognizing and responding to vitamin D in the immune/inflammation system has widened our view of the essential components of a healthy immune response. Nonetheless, many key questions remain to be addressed. These include the cell type-specific roles of VDR in the progression of inflammatory diseases and the mechanisms of cross talk between VDR and other nuclear receptors, such as the retinoid X receptor and liver X receptor, which stimulate the intracellular pathway to exert the anti-inflammation effect. In addition, a single measurement of serum vitamin D status or the current standard value is unlikely to be valid in all situations. The development of research to refine existing biomarkers or establish new indicators that takes many factors into account and to identify useful functional biomarkers of vitamin D status in specific tissues will offer key insights into the development of targeted therapies for individuals with functional vitamin D insufficiency or deficiency in inflammatory diseases, though the research methodology for these potential biomarkers remains to be elucidated.

\section{Acknowledgment}

This work was supported by research grants HL112597, HL116042, and HL120659 from the US National Institutes of Health to DKA. The content of this review is solely the responsibility of the authors, and does not necessarily represent the official views of the NIH.

\section{Disclosure}

The authors report no conflicts of interest in this work.

\section{References}

1. Holick MF. Vitamin D deficiency. N Engl J Med. 2007;357:266-281.

2. Langlois M, Duprez D, Delanghe J, De Buyzere M, Clement DL. Serum vitamin $\mathrm{C}$ concentration is low in peripheral arterial disease and is associated with inflammation and severity of atherosclerosis. Circulation. 2001;103:1863-1868. 
3. Pittas AG, Harris SS, Stark PC, Dawson-Hughes B. The effects of calcium and vitamin D supplementation on blood glucose and markers of inflammation in nondiabetic adults. Diabetes Care. 2007;30: 980-986.

4. Wu S, Sun J. Vitamin D, vitamin D receptor, and macroautophagy in inflammation and infection. Discov Med. 2011;11:325-335.

5. White JH. Vitamin D signaling, infectious diseases, and regulation of innate immunity. Infect Immun. 2008;76:3837-3843.

6. Tiosano D, Wildbaum G, Gepstein V, et al. The role of vitamin D receptor in innate and adaptive immunity: a study in hereditary vitamin D-resistant rickets patients. J Clin Endocrinol Metab. 2013;98: 1685-1693.

7. Olliver M, Spelmink L, Hiew J, Meyer-Hoffert U, HenriquesNormark B, Bergman P. Immunomodulatory effects of vitamin D on innate and adaptive immune responses to Streptococcus pneumoniae. J Infect Dis. 2013;208:1474-1481.

8. Logan VF, Gray AR, Peddie MC, Harper MJ, Houghton LA. Long-term vitamin D3 supplementation is more effective than vitamin D2 in maintaining serum 25-hydroxyvitamin D status over the winter months. Br J Nutr. 2013;109:1082-1088.

9. Armas LA, Hollis BW, Heaney RP. Vitamin D2 is much less effective than vitamin D3 in humans. $J$ Clin Endocrinol Metab. 2004;89: 5387-5391.

10. Querfeld U. Vitamin D and inflammation. Pediatr Nephrol. 2013;28: 605-610.

11. Nagy L, Szanto A, Szatmari I, Szeles L. Nuclear hormone receptors enable macrophages and dendritic cells to sense their lipid environment and shape their immune response. Physiol Rev. 2012;92:739-789.

12. Brennan A, Katz DR, Nunn JD, et al. Dendritic cells from human tissues express receptors for the immunoregulatory vitamin D3 metabolite, dihydroxycholecalciferol. Immunology. 1987;61:457-461.

13. Rosen CJ. Clinical practice. Vitamin D insufficiency. $N$ Engl J Med. 2011;364:248-254.

14. Liu LC, Voors AA, van Veldhuisen DJ, et al. Vitamin D status and outcomes in heart failure patients. Eur J Heart Fail. 2011;13:619-625.

15. Björkhem-Bergman L, Nylén H, Norlin AC, et al. Serum levels of 25 -hydroxyvitamin D and the CYP3A biomarker $4 \beta$-hydroxycholesterol in a high-dose vitamin D supplementation study. Drug Metab Dispos. 2013;41:704-708.

16. Hopkins MH, Owen J, Ahearn T, et al. Effects of supplemental vitamin D and calcium on biomarkers of inflammation in colorectal adenoma patients: a randomized, controlled clinical trial. Cancer Prev Res (Phila). 2011;4:1645-1654.

17. Ponda MP, Huang X, Odeh MA, Breslow JL, Kaufman HW. Vitamin D may not improve lipid levels: a serial clinical laboratory data study. Circulation. 2012;126:270-277.

18. Kreutz M, Andreesen R, Krause SW, Szabo A, Ritz E, Reichel H. 1,25-Dihydroxyvitamin D3 production and vitamin D3 receptor expression are developmentally regulated during differentiation of human monocytes into macrophages. Blood. 1993;82:1300-1307.

19. Liu PT, Stenger S, Li H, et al. Toll-like receptor triggering of a vitamin D-mediated human antimicrobial response. Science. 2006;311: 1770-1773.

20. Krutzik SR, Hewison M, Liu PT, et al. IL-15 links TLR2/1-induced macrophage differentiation to the vitamin D-dependent antimicrobial pathway. J Immunol. 2008;181:7115-7120.

21. Korf H, Wenes M, Stijlemans B, et al. 1,25-Dihydroxyvitamin D3 curtails the inflammatory and $\mathrm{T}$ cell stimulatory capacity of macrophages through an IL-10-dependent mechanism. Immunobiology. 2012;217:1292-1300.

22. Chen Y, Liu W, Sun T, et al. 1,25-Dihydroxyvitamin D promotes negative feedback regulation of TLR signaling via targeting microRNA-155-SOCS1 in macrophages. J Immunol. 2013;190: 3687-3695.

23. Zhang Y, Leung DY, Richers BN, et al. Vitamin D inhibits monocyte/ macrophage proinflammatory cytokine production by targeting MAPK phosphatase-1. J Immunol. 2012;188:2127-2135.
24. Ohta M, Okabe T, Ozawa K, Urabe A, Takaku F. $1 \alpha, 25$-Dihydroxyvitamin D3 (calcitriol) stimulates proliferation of human circulating monocytes in vitro. FEBS Lett. 1985;185:9-13.

25. Sanchez-Niño MD, Bozic M, Córdoba-Lanús E, et al. Beyond proteinuria: VDR activation reduces renal inflammation in experimental diabetic nephropathy. Am J Physiol Renal Physiol. 2012;302: F647-F657.

26. Riek AE, Oh J, Sprague JE, et al. Vitamin D suppression of endoplasmic reticulum stress promotes an antiatherogenic monocyte/macrophage phenotype in type 2 diabetic patients. $J$ Biol Chem. 2012;287: 38482-38494.

27. Helming L, Bose J, Ehrchen J, et al. 1 $\alpha, 25$-Dihydroxyvitamin D3 is a potent suppressor of interferon $\gamma$-mediated macrophage activation. Blood. 2005;106:4351-4358.

28. White JH. Vitamin D metabolism and signaling in the immune system. Rev Endocr Metab Disord. 2012;13:21-29.

29. Griffin MD, Lutz W, Phan VA, Bachman LA, McKean DJ, Kumar R. Dendritic cell modulation by 1alpha, 25 dihydroxyvitamin D3 and its analogs: a vitamin D receptor-dependent pathway that promotes a persistent state of immaturity in vitro and in vivo. Proc Natl Acad Sci U S A. 2001;98:6800-6805.

30. Piemonti L, Monti P, Sironi M, et al. Vitamin D3 affects differentiation, maturation, and function of human monocyte-derived dendritic cells. J Immunol. 2000;164:4443-4451.

31. Takeda M, Yamashita T, Sasaki N, et al. Oral administration of an active form of vitamin D3 (calcitriol) decreases atherosclerosis in mice by inducing regulatory $\mathrm{T}$ cells and immature dendritic cells with tolerogenic functions. Arterioscler Thromb Vasc Biol. 2010;30: 2495-2503.

32. Mayne CG, Spanier JA, Relland LM, Williams CB, Hayes CE. 1,25Dihydroxyvitamin D3 acts directly on the T lymphocyte vitamin D receptor to inhibit experimental autoimmune encephalomyelitis. Eur J Immunol. 2011;41:822-832

33. von Essen MR, Kongsbak M, Schjerling P, Olgaard K, Odum N, Geisler C. Vitamin D controls T cell antigen receptor signaling and activation of human T cells. Nat Immunol. 2010;11:344-349.

34. Jeffery LE, Burke F, Mura M, et al. 1,25-Dihydroxyvitamin D3 and IL-2 combine to inhibit $\mathrm{T}$ cell production of inflammatory cytokines and promote development of regulatory T cells expressing CTLA-4 and FoxP3. J Immunol. 2009;183:5458-5467.

35. Edfeldt K, Liu PT, Chun R, et al. T-cell cytokines differentially control human monocyte antimicrobial responses by regulating vitamin $\mathrm{D}$ metabolism. Proc Natl Acad Sci U S A. 2010;107:22593-22598.

36. White AN, Ng V, Spain CV, Johnson CC, Kinlin LM, Fisman DN. Let the sun shine in: effects of ultraviolet radiation on invasive pneumococcal disease risk in Philadelphia, Pennsylvania. BMC Infect Dis. 2009;9:196.

37. Science M, Maguire JL, Russell ML, Smieja M, Walter SD, Loeb M. Low serum 25-hydroxyvitamin D level and risk of upper respiratory tract infection in children and adolescents. Clin Infect Dis. 2013;57: 392-397.

38. Mohamed WA, Al-Shehri MA. Cord blood 25-hydroxyvitamin D levels and the risk of acute lower respiratory tract infection in early childhood. J Trop Pediatr. 2013;59:29-35.

39. Berry DJ, Hesketh K, Power C, Hypponen E. Vitamin D status has a linear association with seasonal infections and lung function in British adults. Br J Nutr. 2011;106:1433-1440.

40. Sabetta JR, DePetrillo P, Cipriani RJ, Smardin J, Burns LA, Landry ML Serum 25-hydroxyvitamin $D$ and the incidence of acute viral respiratory tract infections in healthy adults. PLoS One. 2010;5:e11088.

41. Ginde AA, Mansbach JM, Camargo CA Jr. Association between serum 25-hydroxyvitamin D level and upper respiratory tract infection in the Third National Health and Nutrition Examination Survey. Arch Intern Med. 2009;169:384-390.

42. Laaksi I, Ruohola JP, Tuohimaa P, et al. An association of serum vitamin D concentrations $<40 \mathrm{nmol} / \mathrm{L}$ with acute respiratory tract infection in young Finnish men. Am J Clin Nutr. 2007;86:714-717. 
43. Camargo CA Jr, Ganmaa D, Frazier AL, et al. Randomized trial of vitamin D supplementation and risk of acute respiratory infection in Mongolia. Pediatrics. 2012;130:e561-e567.

44. Laaksi I, Ruohola JP, Mattila V, Auvinen A, Ylikomi T, Pihlajamäki H. Vitamin D supplementation for the prevention of acute respiratory tract infection: a randomized, double-blinded trial among young Finnish men. J Infect Dis. 2010;202:809-814.

45. Ehrchen J, Helming L, Varga G, et al. Vitamin D receptor signaling contributes to susceptibility to infection with Leishmania major. FASEB J. 2007;21:3208-3218.

46. He Q, Ananaba GA, Patrickson J, et al. Chlamydial infection in vitamin D receptor knockout mice is more intense and prolonged than in wild-type mice. J Steroid Biochem Mol Biol. 2013;135:7-14.

47. Schauber J, Dorschner RA, Coda AB, et al. Injury enhances TLR2 function and antimicrobial peptide expression through a vitamin Ddependent mechanism. J Clin Invest. 2007;117:803-811.

48. Whitcomb JP, Deagostino M, Ballentine M, et al. The role of vitamin D and vitamin D receptor in immunity to Leishmania major infection. $J$ Parasitol Res. 2012;2012:134645.

49. Yang HF, Zhang ZH, Chang ZQ, Tang KL, Lin DZ, Xu JZ. Vitamin D deficiency affects the immunity against Mycobacterium tuberculosis infection in mice. Clin Exp Med. 2013;13:265-270.

50. Anandaiah A, Sinha S, Bole M, et al. Vitamin D rescues impaired Mycobacterium tuberculosis-mediated tumor necrosis factor release in macrophages of HIV-seropositive individuals through an enhanced Tolllike receptor signaling pathway in vitro. Infect Immun. 2013;81:2-10.

51. Amer M, Qayyum R. Relation between serum 25-hydroxyvitamin D and C-reactive protein in asymptomatic adults (from the continuous National Health and Nutrition Examination Survey 2001 to 2006). Am J Cardiol. 2012;109:226-230.

52. Lucidarme O, Messai E, Mazzoni T, Arcade M, du Cheyron D. Incidence and risk factors of vitamin D deficiency in critically ill patients: results from a prospective observational study. Intensive Care Med. 2010;36:1609-1611.

53. Trilok-Kumar G, Arora H, Rajput M, et al. Effect of vitamin D supplementation of low birth weight term Indian infants from birth on cytokine production at 6 months. Eur J Clin Nutr. 2012;66:746-750.

54. Alagarasu K, Honap T, Mulay AP, Bachal RV, Shah PS, Cecilia D. Association of vitamin D receptor gene polymorphisms with clinical outcomes of dengue virus infection. Hum Immunol. 2012;73: 1194-1199.

55. Aslan S, Akil I, Aslan G, Onay H, Ozyurt BC, Ozkinay F. Vitamin D receptor gene polymorphism in children with urinary tract infection. Pediatr Nephrol. 2012;27:417-421.

56. Rathored J, Sharma SK, Singh B, et al. Risk and outcome of multidrugresistant tuberculosis: vitamin $\mathrm{D}$ receptor polymorphisms and serum 25(OH)D. Int J Tuberc Lung Dis. 2012;16:1522-1528.

57. Levin GP, Robinson-Cohen $\mathrm{C}$, de Boer IH, et al. Genetic variants and associations of 25-hydroxyvitamin $\mathrm{D}$ concentrations with major clinical outcomes. JAMA. 2012;308:1898-1905.

58. Yin K, Deng X, Mo ZC, et al. Tristetraprolin-dependent posttranscriptional regulation of inflammatory cytokine mRNA expression by apolipoprotein A-I: role of ATP-binding membrane cassette transporter A1 and signal transducer and activator of transcription 3. J Biol Chem. 2011;286:13834-13845.

59. Kassi E, Adamopoulos C, Basdra EK, Papavassiliou AG. Role of vitamin D in atherosclerosis. Circulation. 2013;128:2517-2531.

60. Stojanovic OI, Lazovic M, Vuceljic M. Association between atherosclerosis and osteoporosis, the role of vitamin D. Arch Med Sci. 2011;7: 179-188.

61. Merke J, Milde P, Lewicka S, et al. Identification and regulation of 1,25-dihydroxyvitamin D3 receptor activity and biosynthesis of 1,25dihydroxyvitamin D3. Studies in cultured bovine aortic endothelial cells and human dermal capillaries. J Clin Invest. 1989;83:1903-1915.

62. Rebsamen MC, Sun J, Norman AW, Liao JK. 1 $\alpha, 25$-Dihydroxyvitamin D3 induces vascular smooth muscle cell migration via activation of phosphatidylinositol 3-kinase. Circ Res. 2002;91:17-24.
63. Wang H, Xia N, Yang Y, Peng DQ. Influence of vitamin D supplementation on plasma lipid profiles: a meta-analysis of randomized controlled trials. Lipids Health Dis. 2012;11:42.

64. Park S, Lee BK. Vitamin D deficiency is an independent risk factor for cardiovascular disease in Koreans aged $\geq 50$ years: results from the Korean National Health and Nutrition Examination Survey. Nutr Res Pract. 2012;6:162-168.

65. Martins D, Wolf M, Pan D, et al. Prevalence of cardiovascular risk factors and the serum levels of 25-hydroxyvitamin D in the United States: data from the Third National Health and Nutrition Examination Survey. Arch Intern Med. 2007;167:1159-1165.

66. Zhao G, Ford ES, Li C, Croft JB. Serum 25-hydroxyvitamin D levels and all-cause and cardiovascular disease mortality among US adults with hypertension: the NHANES linked mortality study. J Hypertens. 2012;30:284-289.

67. Wasson LT, Shimbo D, Rubin MR, Shaffer JA, Schwartz JE, Davidson KW. Is vitamin D deficiency a risk factor for ischemic heart disease in patients with established cardiovascular disease? 10-Year follow-up of the Nova Scotia Health Survey. Int J Cardiol. 2011;148: 387-389.

68. Semba RD, Houston DK, Bandinelli S, et al. Relationship of 25hydroxyvitamin $\mathrm{D}$ with all-cause and cardiovascular disease mortality in older community-dwelling adults. Eur J Clin Nutr. 2010;64: 203-209.

69. Wang TJ, Pencina MJ, Booth SL, et al. Vitamin D deficiency and risk of cardiovascular disease. Circulation. 2008;117:503-511.

70. Dobnig H, Pilz S, Scharnagl H, et al. Independent association of low serum 25-hydroxyvitamin D and 1,25-dihydroxyvitamin D levels with all-cause and cardiovascular mortality. Arch Intern Med. 2008;168:1340-1349.

71. Lim S, Shin H, Kim MJ, et al. Vitamin D inadequacy is associated with significant coronary artery stenosis in a community-based elderly cohort: the Korean Longitudinal Study on Health and Aging. J Clin Endocrinol Metab. 2012;97:169-178.

72. Harris RA, Pedersen-White J, Guo DH, et al. Vitamin D3 supplementation for 16 weeks improves flow-mediated dilation in overweight African-American adults. Am J Hypertens. 2011;24:557-562.

73. Zittermann A, Frisch S, Berthold HK, et al. Vitamin D supplementation enhances the beneficial effects of weight loss on cardiovascular disease risk markers. Am J Clin Nutr. 2009;89:1321-1327.

74. Sun Q, Shi L, Rimm EB, et al. Vitamin D intake and risk of cardiovascular disease in US men and women. Am J Clin Nutr. 2011;94:534-542.

75. Cauley JA, Chlebowski RT, Wactawski-Wende J, et al. Calcium plus vitamin D supplementation and health outcomes five years after active intervention ended: the Women's Health Initiative. $J$ Womens Health (Larchmt). 2013;22:915-929.

76. Gepner AD, Ramamurthy R, Krueger DC, Korcarz CE, Binkley N, Stein JH. A prospective randomized controlled trial of the effects of vitamin D supplementation on cardiovascular disease risk. PLoS One. 2012;7:e36617.

77. Ponda MP, Dowd K, Finkielstein D, Holt PR, Breslow JL. The short-term effects of vitamin D repletion on cholesterol: a randomized, placebocontrolled trial. Arterioscler Thromb Vasc Biol. 2012;32:2510-2515.

78. Yiu YF, Yiu KH, Siu CW, et al. Randomized controlled trial of vitamin D supplement on endothelial function in patients with type 2 diabetes. Atherosclerosis. 2013;227:140-146.

79. Wong MS, Delansorne R, Man RY, Svenningsen P, Vanhoutte PM. Chronic treatment with vitamin D lowers arterial blood pressure and reduces endothelium-dependent contractions in the aorta of the spontaneously hypertensive rat. Am J Physiol Heart Circ Physiol. 2010;299: H1226-H1234.

80. Krishnan AV, Feldman D. Molecular pathways mediating the antiinflammatory effects of calcitriol: implications for prostate cancer chemoprevention and treatment. Endocr Relat Cancer. 2010;17:R19-R38.

81. Oh J, Weng S, Felton SK, et al. 1,25(OH)2 vitamin D inhibits foam cell formation and suppresses macrophage cholesterol uptake in patients with type 2 diabetes mellitus. Circulation. 2009;120:687-698. 
82. Gupta GK, Agrawal T, DelCore MG, Mohiuddin SM, Agrawal DK. Vitamin D deficiency induces cardiac hypertrophy and inflammation in epicardial adipose tissue in hypercholesterolemic swine. Exp $\mathrm{Mol}$ Pathol. 2012;93:82-90.

83. Carthy EP, Yamashita W, Hsu A, Ooi BS. 1,25-Dihydroxyvitamin D3 and rat vascular smooth muscle cell growth. Hypertension. 1989;13:954-959.

84. Tukaj S, Trzonkowski P, Tukaj C. Regulatory effects of 1,25dihydroxyvitamin D3 on vascular smooth muscle cells. Acta Biochim Pol. 2012;59:395-400.

85. Gupta GK, Agrawal T, Del Core MG, Hunter WJ 3rd, Agrawal DK. Decreased expression of vitamin D receptors in neointimal lesions following coronary artery angioplasty in atherosclerotic swine. PLoS One. 2012;7:e42789.

86. Finklea JD, Grossmann RE, Tangpricha V. Vitamin D and chronic lung disease: a review of molecular mechanisms and clinical studies. Adv Nutr. 2011;2:244-253.

87. Camargo CA Jr, Rifas-Shiman SL, Litonjua AA, et al. Maternal intake of vitamin D during pregnancy and risk of recurrent wheeze in children at 3 y of age. Am J Clin Nutr. 2007;85:788-795.

88. Erkkola M, Kaila M, Nwaru BI, et al. Maternal vitamin D intake during pregnancy is inversely associated with asthma and allergic rhinitis in 5-year-old children. Clin Exp Allergy. 2009;39:875-882

89. Freishtat RJ, Iqbal SF, Pillai DK, et al. High prevalence of vitamin D deficiency among inner-city African American youth with asthma in Washington, DC. J Pediatr. 2010;156:948-952.

90. Goleva E, Searing DA, Jackson LP, Richers BN, Leung DY. Steroid requirements and immune associations with vitamin $\mathrm{D}$ are stronger in children than adults with asthma. J Allergy Clin Immunol. 2012;129: 1243-1251.

91. Korn S, Hübner M, Jung M, Blettner M, Buhl R. Severe and uncontrolled adult asthma is associated with vitamin D insufficiency and deficiency. Respir Res. 2013;14:25.

92. Morales E, Romieu I, Guerra S, et al. Maternal vitamin D status in pregnancy and risk of lower respiratory tract infections, wheezing, and asthma in offspring. Epidemiology. 2012;23:64-71.

93. Bener A, Ehlayel MS, Tulic MK, Hamid Q. Vitamin D deficiency as a strong predictor of asthma in children. Int Arch Allergy Immunol. 2012;157:168-175.

94. Brehm JM, Schuemann B, Fuhlbrigge AL, et al. Serum vitamin D levels and severe asthma exacerbations in the Childhood Asthma Management Program study. J Allergy Clin Immunol. 2010;126:52-58. e5.

95. Gale CR, Robinson SM, Harvey NC, et al. Maternal vitamin D status during pregnancy and child outcomes. Eur J Clin Nutr. 2008;62: 68-77.

96. Song Y, Qi H, Wu C. Effect of 1,25-(OH)2D3 (a vitamin D analogue) on passively sensitized human airway smooth muscle cells. Respirology. 2007;12:486-494.

97. Xystrakis E, Kusumakar S, Boswell S, et al. Reversing the defective induction of IL-10-secreting regulatory $\mathrm{T}$ cells in glucocorticoidresistant asthma patients. J Clin Invest. 2006;116:146-155.

98. Gorman S, Tan DH, Lambert MJ, Scott NM, Judge MA, Hart PH. Vitamin $\mathrm{D}(3)$ deficiency enhances allergen-induced lymphocyte responses in a mouse model of allergic airway disease. Pediatr Allergy Immunol. 2012;23:83-87.

99. Agrawal T, Gupta GK, Agrawal DK. Vitamin D deficiency decreases the expression of VDR and prohibitin in the lungs of mice with allergic airway inflammation. Exp Mol Pathol. 2012;93:74-81.

100. Ananthakrishnan AN, Khalili H, Higuchi LM, et al. Higher predicted vitamin D status is associated with reduced risk of Crohn's disease. Gastroenterology. 2012;142:482-489.

101. Levin AD, Wadhera V, Leach ST, et al. Vitamin D deficiency in children with inflammatory bowel disease. Dig Dis Sci. 2011;56:830-836.

102. Ulitsky A, Ananthakrishnan AN, Naik A, et al. Vitamin D deficiency in patients with inflammatory bowel disease: association with disease activity and quality of life. JPEN J Parenter Enteral Nutr. 2011;35: 308-316.
103. Pappa HM, Gordon CM, Saslowsky TM, et al. Vitamin D status in children and young adults with inflammatory bowel disease. Pediatrics. 2006;118:1950-1961.

104. Sentongo TA, Semaeo EJ, Stettler N, Piccoli DA, Stallings VA, Zemel BS. Vitamin D status in children, adolescents, and young adults with Crohn disease. Am J Clin Nutr. 2002;76:1077-1081.

105. Jahnsen J, Falch JA, Mowinckel P, Aadland E. Vitamin D status, parathyroid hormone and bone mineral density in patients with inflammatory bowel disease. Scand J Gastroenterol. 2002;37:192-199.

106. Jørgensen SP, Agnholt J, Glerup H, et al. Clinical trial: vitamin D3 treatment in Crohn's disease - a randomized double-blind placebocontrolled study. Aliment Pharmacol Ther. 2010;32:377-383.

107. Yang L, Weaver V, Smith JP, Bingaman S, Hartman TJ, Cantorna MT. Therapeutic effect of vitamin D supplementation in a pilot study of Crohn's patients. Clin Transl Gastroenterol. 2013;4:e33.

108. Pappa HM, Mitchell PD, Jiang H, et al. Treatment of vitamin D insufficiency in children and adolescents with inflammatory bowel disease: a randomized clinical trial comparing three regimens. J Clin Endocrinol Metab. 2012;97:2134-2142.

109. Miheller P, Muzes G, Hritz I, et al. Comparison of the effects of 1,25 dihydroxyvitamin D and 25 hydroxyvitamin D on bone pathology and disease activity in Crohn's disease patients. Inflamm Bowel Dis. 2009; $15: 1656-1662$.

110. Kong J, Zhang Z, Musch MW, et al. Novel role of the vitamin D receptor in maintaining the integrity of the intestinal mucosal barrier Am J Physiol Gastrointest Liver Physiol. 2008;294:G208-G216.

111. Ryz NR, Patterson SJ, Zhang Y, et al. Active vitamin D (1,25dihydroxyvitamin D3) increases host susceptibility to Citrobacter rodentium by suppressing mucosal Th17 responses. Am J Physiol Gastrointest Liver Physiol. 2012;303:G1299-G1311.

112. Ali FN, Arguelles LM, Langman CB, Price HE. Vitamin D deficiency in children with chronic kidney disease: uncovering an epidemic. Pediatrics. 2009;123:791-796.

113. Satirapoj B, Limwannata P, Chaiprasert A, Supasyndh O, Choovichian P. Vitamin D insufficiency and deficiency with stages of chronic kidney disease in an Asian population. BMC Nephrol. 2013;14:206.

114. Isakova T, Gutiérrez OM, Patel NM, Andress DL, Wolf M, Levin A. Vitamin D deficiency, inflammation, and albuminuria in chronic kidney disease: complex interactions. J Ren Nutr. 2011;21: 295-302.

115. Petchey WG, Howden EJ, Johnson DW, Hawley CM, Marwick T, Isbel NM. Cardiorespiratory fitness is independently associated with 25-hydroxyvitamin D in chronic kidney disease. Clin J Am Soc Nephrol. 2011;6:512-518.

116. Pilz S, Tomaschitz A, Friedl C, et al. Vitamin D status and mortality in chronic kidney disease. Nephrol Dial Transplant. 2011;26: 3603-3609.

117. Santoro D, Gitto L, Ferraro A, Satta E, Savica V, Bellinghieri G. Vitamin D status and mortality risk in patients with chronic kidney disease. Ren Fail. 2011;33:184-191.

118. Seeherunvong W, Abitbol CL, Chandar J, Zilleruelo G, Freundlich M. Vitamin D insufficiency and deficiency in children with early chronic kidney disease. J Pediatr. 2009;154:906-911. e1.

119. London GM, Guérin AP, Verbeke FH, et al. Mineral metabolism and arterial functions in end-stage renal disease: potential role of 25-hydroxyvitamin D deficiency. J Am Soc Nephrol. 2007;18: 613-620.

120. Molina P, Górriz JL, Molina MD, et al. The effect of cholecalciferol for lowering albuminuria in chronic kidney disease: a prospective controlled study. Nephrol Dial Transplant. 2014;29:97-109.

121. Schaible J, Wigger M, Staude H, et al. Serum fetuin-A and vitamin D in children with mild-to-severe chronic kidney disease: a cross-sectional study. Nephrol Dial Transplant. 2012;27:1107-1113.

122. Alvarez JA, Law J, Coakley KE, et al. High-dose cholecalciferol reduces parathyroid hormone in patients with early chronic kidney disease: a pilot, randomized, double-blind, placebo-controlled trial. Am J Clin Nutr. 2012;96:672-679. 
123. Alvarez JA, Zughaier SM, Law J, et al. Effects of high-dose cholecalciferol on serum markers of inflammation and immunity in patients with early chronic kidney disease. Eur J Clin Nutr. 2013;67: 264-269.

124. Chandra P, Binongo JN, Ziegler TR, et al. Cholecalciferol (vitamin D3) therapy and vitamin D insufficiency in patients with chronic kidney disease: a randomized controlled pilot study. Endocr Pract. 2008;14: $10-17$.

125. Kooienga L, Fried L, Scragg R, Kendrick J, Smits G, Chonchol M. The effect of combined calcium and vitamin D3 supplementation on serum intact parathyroid hormone in moderate CKD. Am J Kidney Dis. 2009;53:408-416.

126. Marckmann P, Agerskov H, Thineshkumar S, et al. Randomized controlled trial of cholecalciferol supplementation in chronic kidney disease patients with hypovitaminosis D. Nephrol Dial Transplant. 2012;27:3523-3531.

127. Shroff R, Wan M, Gullett A, et al. Ergocalciferol supplementation in children with $\mathrm{CKD}$ delays the onset of secondary hyperparathyroidism: a randomized trial. Clin J Am Soc Nephrol. 2012;7:216-223.

128. Stubbs JR, Idiculla A, Slusser J, Menard R, Quarles LD. Cholecalciferol supplementation alters calcitriol-responsive monocyte proteins and decreases inflammatory cytokines in ESRD. J Am Soc Nephrol. 2010;21:353-361.

129. Zisman AL, Hristova M, Ho LT, Sprague SM. Impact of ergocalciferol treatment of vitamin D deficiency on serum parathyroid hormone concentrations in chronic kidney disease. Am J Nephrol. 2007;27: $36-43$.

130. Albalate M, de la Piedra C, Ortiz A, et al. Risk in dosing regimens for $25-\mathrm{OH}$ vitamin D supplementation in chronic haemodialysis patients. Nephron Clin Pract. 2012;121:c112-c119.

131. Husain K, Ferder L, Mizobuchi M, Finch J, Slatopolsky E. Combination therapy with paricalcitol and enalapril ameliorates cardiac oxidative injury in uremic rats. Am J Nephrol. 2009;29:465-472.

132. Tan X, Wen X, Liu Y. Paricalcitol inhibits renal inflammation by promoting vitamin D receptor-mediated sequestration of NF-kappaB signaling. J Am Soc Nephrol. 2008;19:1741-1752.

133. Brunt EM, Kleiner DE, Wilson LA, et al. Portal chronic inflammation in nonalcoholic fatty liver disease (NAFLD): a histologic marker of advanced NAFLD-clinicopathologic correlations from the nonalcoholic steatohepatitis clinical research network. Hepatology. 2009;49: 809-820.

134. Kelishadi R, Saleka S, Saleka M, Hashemipoura M, Movahedian M. Effects of vitamin D supplementation on insulin resistance and cardiometabolic risk factors in children with metabolic syndrome: a triple-masked controlled trial. J Pediatr (Rio J). 2014;90: 28-34.

135. Wongwiwatthananukit S, Sansanayudh N, Phetkrajaysang N, Krittiyanunt S. Effects of vitamin D(2) supplementation on insulin sensitivity and metabolic parameters in metabolic syndrome patients. J Endocrinol Invest. 2013;36:558-563.

136. Pirgon O, Cekmez F, Bilgin H, Eren E, Dundar B. Low 25hydroxyvitamin D level is associated with insulin sensitivity in obese adolescents with non-alcoholic fatty liver disease. Obes Res Clin Pract. 2013;7:e235-e320.

137. Jablonski KL, Jovanovich A, Holmen J, et al. Low 25-hydroxyvitamin D level is independently associated with non-alcoholic fatty liver disease. Nutr Metab Cardiovasc Dis. 2013;23:792-798.

138. Tilg H, Moschen AR. Evolution of inflammation in nonalcoholic fatty liver disease: the multiple parallel hits hypothesis. Hepatology. 2010;52:1836-1846.

139. Roth CL, Elfers CT, Figlewicz DP, et al. Vitamin D deficiency in obese rats exacerbates nonalcoholic fatty liver disease and increases hepatic resistin and Toll-like receptor activation. Hepatology. 2012;55: 1103-1111.

140. Schaalan MF, Mohamed WA, Amin HH. Vitamin D deficiency: correlation to interleukin-17, interleukin-23 and PIIINP in hepatitis C virus genotype 4. World J Gastroenterol. 2012;18:3738-3744.
141. Zitt E, Sprenger-Mähr H, Knoll F, Neyer U, Lhotta K. Vitamin D deficiency is associated with poor response to active hepatitis B immunisation in patients with chronic kidney disease. Vaccine. 2012;30:931-935.

142. Zúñiga S, Firrincieli D, Housset C, Chignard N. Vitamin D and the vitamin D receptor in liver pathophysiology. Clin Res Hepatol Gastroenterol. 2011;35:295-302.

143. Mowry EM, Waubant E, McCulloch CE, et al. Vitamin D status predicts new brain magnetic resonance imaging activity in multiple sclerosis. Ann Neurol. 2012;72:234-240.

144. Martinelli V, Dalla Costa G, Colombo B, et al. Vitamin D levels and risk of multiple sclerosis in patients with clinically isolated syndromes. Mult Scler. 2014;20:147-155.

145. Munger KL, Levin LI, Hollis BW, Howard NS, Ascherio A. Serum 25-hydroxyvitamin $\mathrm{D}$ levels and risk of multiple sclerosis. JAMA. 2006;296:2832-2838.

146. Pierrot-Deseilligny C, Rivaud-Péchoux S, Clerson P, de Paz R, Souberbielle JC. Relationship between 25-OH-D serum level and relapse rate in multiple sclerosis patients before and after vitamin D supplementation. Ther Adv Neurol Disord. 2012;5:187-198.

147. Mirzaei F, Michels KB, Munger K, et al. Gestational vitamin D and the risk of multiple sclerosis in offspring. Ann Neurol. 2011;70:30-40.

148. Burton JM, Kimball S, Vieth R, et al. A phase I/II dose-escalation trial of vitamin D3 and calcium in multiple sclerosis. Neurology. 2010;74:1852-1859.

149. Shaygannejad V, Janghorbani M, Ashtari F, Dehghan H. Effects of adjunct low-dose vitamin $\mathrm{D}$ on relapsing-remitting multiple sclerosis progression: preliminary findings of a randomized placebo-controlled trial. Mult Scler Int. 2012;2012:452541.

150. Kampman MT, Steffensen LH, Mellgren SI, Jørgensen L. Effect of vitamin D3 supplementation on relapses, disease progression, and measures of function in persons with multiple sclerosis: exploratory outcomes from a double-blind randomised controlled trial. Mult Scler. 2012;18:1144-1151.

151. Smolders J, Peelen E, Thewissen M, et al. Safety and T cell modulating effects of high dose vitamin D3 supplementation in multiple sclerosis. PLoS One. 2010;5:e15235.

152. Adzemovic MZ, Zeitelhofer M, Hochmeister S, Gustafsson SA, Jagodic M. Efficacy of vitamin D in treating multiple sclerosis-like neuroinflammation depends on developmental stage. Exp Neurol. 2013;249:39-48.

153. Ozfirat Z, Chowdhury TA. Vitamin D deficiency and type 2 diabetes. Postgrad Med J. 2010;86:18-25; quiz 24.

154. Tamez H, Thadhani RI. Vitamin D and hypertension: an update and review. Curr Opin Nephrol Hypertens. 2012;21:492-499.

155. Sugden JA, Davies JI, Witham MD, Morris AD, Struthers AD. Vitamin D improves endothelial function in patients with type 2 diabetes mellitus and low vitamin D levels. Diabet Med. 2008;25: 320-325.

156. Forman JP, Scott JB, Ng K, et al. Effect of vitamin D supplementation on blood pressure in blacks. Hypertension. 2013;61:779-785.

157. Asemi Z, Hashemi T, Karamali M, Samimi M, Esmaillzadeh A. Effects of vitamin D supplementation on glucose metabolism, lipid concentrations, inflammation, and oxidative stress in gestational diabetes: a double-blind randomized controlled clinical trial. Am J Clin Nutr. 2013;98:1425-1432.

158. Witham MD, Ireland S, Houston JG, et al. Vitamin D therapy to reduce blood pressure and left ventricular hypertrophy in resistant hypertension: randomized, controlled trial. Hypertension. 2014;63:706-712.

159. Lewis PJ. Vitamin D deficiency may have role in chronic low back pain. BMJ. 2005;331:109.

160. Sandoughi M, Zakeri Z, Mirhosainee Z, Mohammadi M, Shahbakhsh S. The effect of vitamin D on nonspecific low back pain. Int J Rheum Dis. Epub October 14, 2013.

161. Boxer RS, Hoit BD, Schmotzer BJ, Stefano GT, Gomes A, Negrea L. The effect of vitamin D on aldosterone and health status in patients with heart failure. J Card Fail. Epub February 4, 2014. 
162. Cantorna MT, Mahon BD: Mounting evidence for vitamin D as an environmental factor affecting autoimmune disease prevalence. Exp Biol Med (Maywood). 2004;229:1136-1142.

163. Abou-Raya A, Abou-Raya S, Helmii M. The effect of vitamin D supplementation on inflammatory and hemostatic markers and disease activity in patients with systemic lupus erythematosus: a randomized placebo-controlled trial. J Rheumatol. 2013;40:265-272.

164. Leventis P, Patel S. Clinical aspects of vitamin D in the management of rheumatoid arthritis. Rheumatology (Oxford). 2008;47:1617-1621.

165. Ritterhouse LL, Crowe SR, Niewold TB, et al. Vitamin D deficiency is associated with an increased autoimmune response in healthy individuals and in patients with systemic lupus erythematosus. Ann Rheum Dis. 2011;70:1569-1574.

166. Kahl LE, Kamboh MI, Decroo S, Ferrell RE. Alpha-1-antitrypsin (PI) and vitamin-D binding globulin (GC) phenotypes in rheumatoid arthritis: absence of an association. Dis Markers. 1989;7:71-78.

167. Ota K, Dambaeva S, Han AR, Beaman K, Gilman-Sachs A, Kwak-Kim J. Vitamin D deficiency may be a risk factor for recurrent pregnancy losses by increasing cellular immunity and autoimmunity. Hum Reprod. 2014;29:208-219.
168. Stricker H, Tosi Bianda F, Guidicelli-Nicolosi S, Limoni C, Colucci G. Effect of a single, oral, high-dose vitamin D supplementation on endothelial function in patients with peripheral arterial disease: a randomised controlled pilot study. Eur J Vasc Endovasc Surg. 2012;44:307-312.

169. Brehm JM, Celedón JC, Soto-Quiros ME, et al. Serum vitamin D levels and markers of severity of childhood asthma in Costa Rica. Am J Respir Crit Care Med. 2009;179:765-771.

170. Moe SM, Saifullah A, LaClair RE, Usman SA, Yu Z. A randomized trial of cholecalciferol versus doxercalciferol for lowering parathyroid hormone in chronic kidney disease. Clin J Am Soc Nephrol. 2010;5: 299-306.

171. Runia TF, Hop WC, de Rijke YB, Buljevac D, Hintzen RQ. Lower serum vitamin $\mathrm{D}$ levels are associated with a higher relapse risk in multiple sclerosis. Neurology. 2012;79:261-266.

172. Munger KL, Chitnis T, Frazier AL, Giovannucci E, Spiegelman D, Ascherio A. Dietary intake of vitamin D during adolescence and risk of multiple sclerosis. J Neurol. 2011;258:479-485.

\section{Publish your work in this journal}

The Journal of Inflammation Research is an international, peer-reviewed open-access journal that welcomes laboratory and clinical findings on the molecular basis, cell biology and pharmacology of inflammation including original research, reviews, symposium reports, hypothesis formation and commentaries on: acute/chronic inflammation; mediators of inflamma-

\section{Dovepress}

tion; cellular processes; molecular mechanisms; pharmacology and novel anti-inflammatory drugs; clinical conditions involving inflammation. The manuscript management system is completely online and includes a very quick and fair peer-review system. Visit http://www.dovepress.com/ testimonials.php to read real quotes from published authors.

Submit your manuscript here: http://www.dovepress.com/journal-of-inflammation-research-journal 